\title{
The Holocene Pulleniatina Minimum Event revisited: Geochemical and faunal evidence from the Okinawa Trough and upper reaches of the Kuroshio current
}

\author{
Yu-Shih Lin ${ }^{\text {a, }}$, Kuo-Yen Wei ${ }^{\text {a,* }}$, In-Tian Lin ${ }^{b}$, Pai-Sen Yu ${ }^{c}$, Hong-Wei Chiang ${ }^{\text {a }}$, \\ Chen-Yin Chen ${ }^{a}$, Chuan-Chou Shen ${ }^{\text {a }}$, Horng-Sheng Mii ${ }^{\mathrm{d}}$, Yue-Gau Chen ${ }^{\mathrm{a}}$ \\ ${ }^{a}$ Department of Geosciences, National Taiwan University, PO Box 13-318, Taipei 106, Taiwan, ROC \\ b Institute of Oceanography, National Taiwan University, Taiwan, ROC \\ ${ }^{\mathrm{c}}$ Institute of Applied Geosciences, National Taiwan Ocean University, Taiwan, ROC \\ ${ }^{\mathrm{d}}$ Department of Earth Sciences, National Taiwan Normal University, Taiwan, ROC
}

Received 26 August 2005; received in revised form 11 February 2006; accepted 14 February 2006

\begin{abstract}
The Holocene Pulleniatina Minimum Event (PME) is characterized by a very low abundance of the planktonic foraminifer Pulleniatina obliquiloculata between $\sim 4.5$ and 3 ka. The PME occurs widely in the Okinawa Trough and the South China Sea, and can be correlated throughout this area; it has been related to variability in the Kuroshio current. To further explore the nature of the PME, we studied cores obtained from the southern Okinawa Trough and the upper reaches of the Kuroshio current. Faunal census data indicate that all cores record the PME between $\sim 4.5$ and $\sim 3 \mathrm{ka}$. The relative abundance of Neogloboquadrina dutertrei is negatively correlated to that of $P$. obliquiloculata in the southern Okinawa Trough, but not in the sites at the upper reaches. $\mathrm{Mg} / \mathrm{Ca}$ and $\delta^{18} \mathrm{O}$ measurements on Globigerinoides ruber shells from the southern Okinawa Trough indicate that there was no change in sea surface temperature or sea surface salinity during the PME. The vertical structure of the water column as reconstructed by multispecies $\delta^{18} \mathrm{O}$ and $\delta^{13} \mathrm{C}$ profiles shows no consistent anomalies in the southern Okinawa Trough and western Philippine Sea during the PME. These observations suggest that: (1) the PME was not restricted to marginal seas, but widespread in the western North Pacific. (2) The high abundance of $N$. dutertrei during the PME in the Okinawa Trough may be a result of higher foodavailability in the absence of $P$. obliquiloculata. (3) No distinctive, consistent anomalies in the paleoceanographic proxies are associated with the PME, implying there were no changes in hydrography and productivity. The absence of a linkage between faunal variation and paleoceanographic proxies indicates that we do not yet understand what causes changes in planktonic foraminiferal assemblages. This lack of understanding implies that we cannot always trust fauna-based paleothermometry at millennial timescales.
\end{abstract}

(C) 2006 Elsevier B.V. All rights reserved.

Keywords: Pulleniatina minimum event; Kuroshio; Holocene; Western North Pacific; $\mathrm{Mg} / \mathrm{Ca}$ ratio; thermocline hydrography

\footnotetext{
* Corresponding author. Tel.: +886 23691143; fax: +886223636095.

E-mail address: weiky@ntu.edu.tw (K.-Y. Wei).

${ }^{1}$ Present address: DFG-Research Center Ocean Margins, Organic Geochemistry Group, University of Bremen, 28334 Bremen, Germany.
} 


\section{Introduction}

During the past decade, paleoceanographers have documented an event called the 'Pulleniatina Minimum Event (PME)', occurring between $\sim 4.5$ and $3 \mathrm{ka}$ in deep-sea cores from the western North Pacific. The PME is characterized by minimum abundance of the planktonic foraminifer Pulleniatina obliquiloculata. The event generally lasted for at least 1000 years. The PME was recorded in several high-resolution cores located under the influence of the Kuroshio in the Okinawa Trough (Li et al., 1997; Jian et al., 2000; Ujiié and Ujiié, 1999; Ujiié et al., 2003a; Ijiri et al., 2005), the South China Sea (Jian et al., 1996; Pflaumann and Jian,
1999; Wang et al., 1999; Yu et al., 2000; Huang et al., 2002; Liu, 2004) and off the eastern coast of Taiwan (Shieh, 1993), whereas at least one core to the east of the Ryukyu Islands does not record the event (Fig. 1). The PME can be correlated over a wide area, and its significance has become an important issue in the Holocene paleoceanography of the western North Pacific. Some authors proposed that $P$. obliquiloculata, a species with its highest abundance in the equatorial current system in the Pacific Ocean (Bé, 1977; Pflaumann and Jian, 1999) (Fig. 2), serves as an indicator of the pathway of the Kuroshio. The marked reduction of $P$. obliquiloculata therefore was said to reflect a weakening or diversion of that current ( $\mathrm{Li}$ et al.,

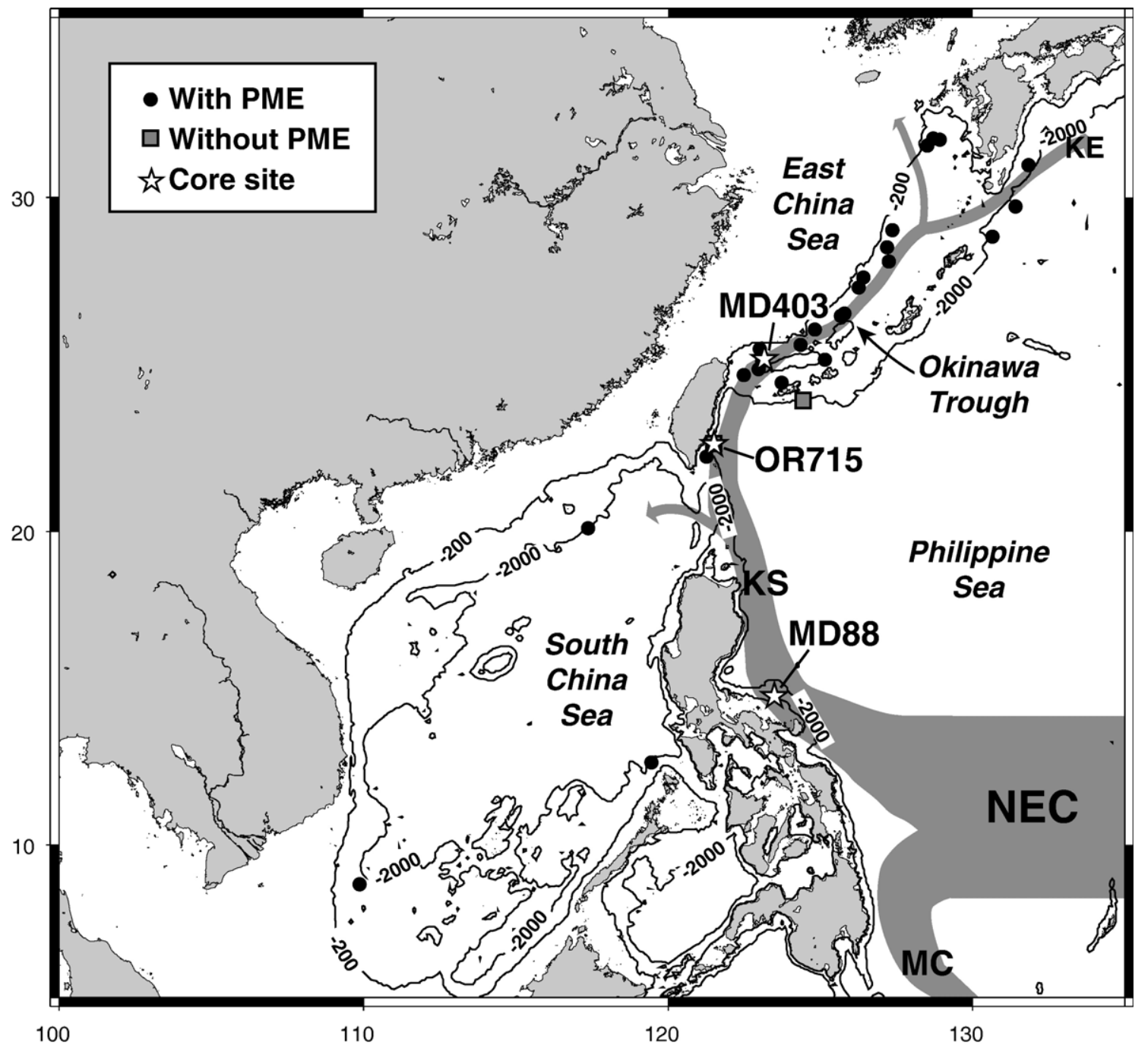

Fig. 1. Occurrence of the PME and the oceanographic settings of the study area. The North Equatorial Current bifurcates into the Kuroshio and the Mindanao Current. Faunal records are from Shieh (1993); Jian et al. (1996, 2000); Li et al. (1997, 2001); Pflaumann and Jian (1999); Ujiié and Ujiié (1999); Yu et al. (2000); Huang et al. (2002); Ujiié et al. (2003a); Liu (2004); Ijiri et al. (2005); Yuan-Pin Chang (personal communication). NEC: North Equatorial Current; KS: Kuroshio; MC: Mindanao Current; KE: Kuroshio Extension. 

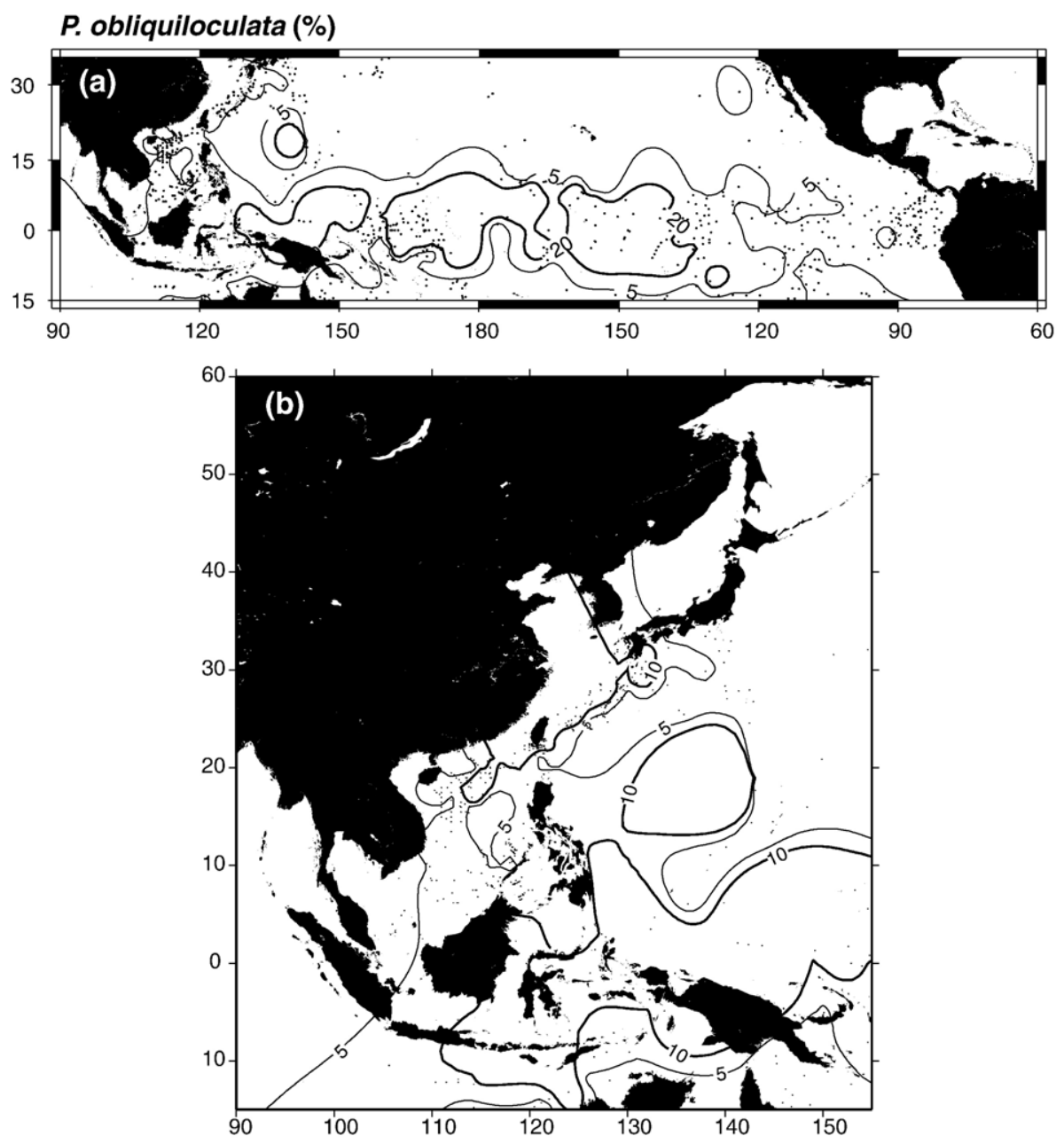

Fig. 2. Relative abundance of $P$. obliquiloculata in surface sediments in the Equatorial Pacific. (a) The relative abundance of $P$. obliquiloculata is highest in the central Equatorial Pacific. (b) In the western North Pacific, the relative abundance of P. obliquiloculata is high in the northern SCS and the Okinawa Trough. Faunal data are from Kucera et al. (2005).

1997; Cheng and Wang, 1998; Ujiié and Ujiié, 1999). Others suggested that an intensification of the winter monsoon and consequently decreased winter sea surface temperatures would have caused the PME (Jian et al., 2000), and that it could be correlated to the Neoglacial cooling in China (Wu and Liu, 2004; Peng et al., 2005). The PME assemblages in the Okinawa Trough are usually marked by a high abundance of Neogloboquadrina dutertrei, a species less abundant in nutrient-rich waters than P. obliquiloculata in the central Equatorial Pacific (Watkins et al., 1998), and therefore Ujiié et al. (2003a) ascribed the PME to the occurrence of El Niñolike conditions, under which $P$. obliquiloculata decreased in abundance due to diminished upwelling of nutrient-rich water in the central Equatorial Pacific, whereas $N$. dutertrei increased in abundance due to an enhanced influence of gyre-margin water in the Okinawa Trough. These interpretations need further investigations because of the limited geographic and proxy coverage in previous studies.

In the present study we specifically addressed the question why species decreased suddenly and significantly in abundance at a millennial timescale. The decrease in the abundance of species of planktonic foraminifera is usually attributed to changes in local hydrographic or nutrient conditions associated with major environmental changes, for example, a glacialinterglacial transition. This explanation is based on the correlation between foraminiferal species distribution and hydrographic properties in the modern ocean, and on the correlation between faunal records and records of geochemical and/or isotope proxies. With the recovery 
of high sedimentation rate cores and the recognition of climate changes at millennial timescales, questions are being raised about the stability of foraminiferal distributions at such timescales, and their relations to environmental changes. The PME occurred in the late Holocene, at a time when climate history is well documented and for which corresponding records are easy to recover. This event thus is an excellent case for detailed study.

We acquired faunal census data from the upper reaches of the Kuroshio current and the southern Okinawa Trough to examine the distribution of the PME in a wider geographic area. In addition, we measured the $\mathrm{Mg} / \mathrm{Ca}$ values of Globigerinoides ruber and oxygen and carbon isotopic ratios in multiple species of planktonic foraminifera in order to investigate the possible link among faunal changes, sea surface temperature (SST), and thermocline hydrography. The wider geographic coverage enabled us to evaluate explanations for the PME, and provided information on the paleoceanographic relations between the open western North Pacific Ocean and the Okinawa Trough.

\section{Oceanographic settings}

The North Equatorial Current bifurcates into the northward flowing Kuroshio and the southward flowing Mindanao Current as it approaches the Philippine coasts (Fig. 1) (Qiu and Lukas, 1996). The Kuroshio, with a mean volume transport of $\sim 15 \mathrm{~Sv}\left(1 \mathrm{~Sv}=10^{6} \mathrm{~m}^{3} \mathrm{~s}^{-1}\right)$ along the east coast of Taiwan and southern Okinawa
Trough (Liang et al., 2003), transports warm, saline and generally oligotrophic water northward. After entering the southern Okinawa Trough, this current is blocked by the continental shelf of the East China Sea, splits, and its eastern extension turns northeastward along the shelf break. The main stream of the Kuroshio exits the trough and becomes the Kuroshio Extension in the north Pacific.

Monsoonal winds and El Niño-Southern Oscillation (ENSO) activity determine the latitude of the North Equatorial Current bifurcation point, which in turn controls the northward volume transport of the Kuroshio (Qu and Lukas, 2003; Kim et al., 2004; Qu et al., 2004). A more southerly position of the bifurcation point during summer favors more transport in the Kuroshio, and vice versa during winter. The Kuroshio transport is weakened during El Niño years and strengthened during La Niña years, but the effect of interannual variability is secondary to the seasonal cycle of volume transport driven by monsoonal winds (Kim et al., 2004).

The three cores used in this study were recovered from the upper reaches of the Kuroshio and the southern Okinawa Trough, respectively (Fig. 1). The term 'upper reaches' refers to the region between the North Equatorial Current bifurcation point $\left(11^{\circ}-20^{\circ} \mathrm{N}\right.$, see Qiu and Lukas, 1996) and the seas off eastern Taiwan. MD98-2188 $\left(123.5^{\circ} \mathrm{E}, 14.8^{\circ} \mathrm{N}\right.$, water depth $730 \mathrm{~m}$, MD88 henceforth; Bassinot et al., 1998), taken from the western Philippine Sea, is located at the northern margin of the Western Pacific Warm Pool. The annual sea surface temperature (SST) at this site is $28.5^{\circ} \mathrm{C}$, and the
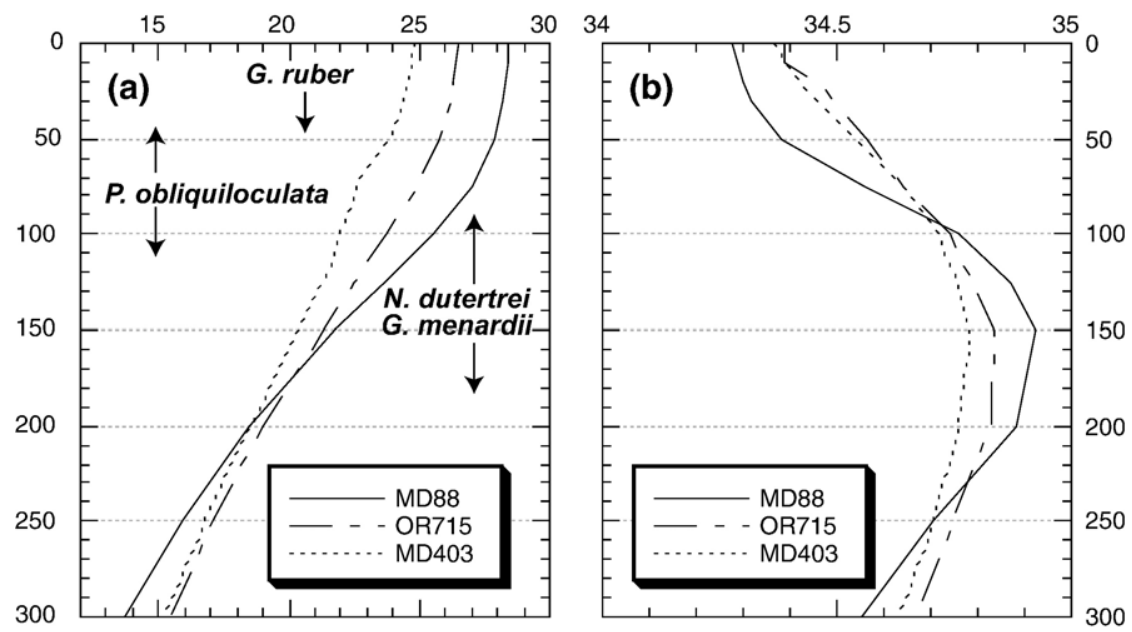

Fig. 3. Vertical hydrographic profiles at the core sites. (a) Temperature profiles at sites MD88, OR715 and MD403. The approximate depth habitats of G. ruber, P. obliquiloculata, N. dutertrei and G. menardii are also indicated according to plankton tow or sediment trap data in adjacent seas (Shieh and Chen, 1990; Lin et al., 2004). See text for discussion. (b) Salinity profiles of the three core sites. Temperature and salinity data are from Levitus and Boyer (1994). 
seawater temperature falls rapidly from $28^{\circ} \mathrm{C}$ at $50 \mathrm{~m}$ to $19^{\circ} \mathrm{C}$ at $200 \mathrm{~m}$ to form a steep thermocline (Levitus and Boyer, 1994) (Fig. 3a). Both OR715-21 (121.5 ${ }^{\circ}$, $22.7^{\circ} \mathrm{N}$, water depth $760 \mathrm{~m}$, OR715 henceforth) and MD01-2403 $\left(123.2^{\circ} \mathrm{E}, 25.3^{\circ} \mathrm{N}\right.$, water depth $1420 \mathrm{~m}$, MD403 henceforth; Bassinot et al., 2002) are beneath the main axis of the Kuroshio. The annual SSTs at OR715 and MD403 are $26.4{ }^{\circ} \mathrm{C}$ and $24.8{ }^{\circ} \mathrm{C}$, respectively. The temperature gradients in the thermocline at OR715 and MD403 are smaller than at MD88. The annual sea surface salinity (SSS) at MD88 is 34.3 p.s.u., 0.1 unit lower than that at OR715 and MD403 (Levitus and Boyer, 1994) (Fig. 3b). The water depths of the three cores are all above the reported depth interval of the regional lysocline (1500-3000 m) (Pan et al., 1988; Thunell et al., 1992).

\section{Materials and methods}

Sediments in the three cores consist of gray clay and silt with few thin ash and turbidite layers in the Holocene sections. All sediment samples were washed through a $63-\mu \mathrm{m}$ screen and divided into aliquots convenient for picking and counting the planktonic foraminifers. To construct the age models, $>6 \mathrm{mg}$ of planktonic foraminiferal shells $(>250 \mu \mathrm{m}$, Globigerinoides spp. and Orbulina universa) were picked from 16 samples in the three cores and subjected to AMS ${ }^{14} \mathrm{C}$ dating at the Rafter Radiocarbon Laboratory, Institute of Geological and Nuclear Sciences, New Zealand. The raw AMS ${ }^{14} \mathrm{C}$ ages were corrected for a 400-year reservoir effect and then converted to calendar ages using CALIB 5.0 program (Stuiver et al., 2005) with dataset Marine04 (Hughen et al., 2004) (Table 1). The sedimentation rates of core MD88 range from 20 to $60 \mathrm{~cm} / \mathrm{kyr}$, equivalent to a temporal resolution of 70-200 years for the $4-\mathrm{cm}$ sampling interval. Core OR715 has uniform sedimentation rates of $20-30 \mathrm{~cm} /$ years except in $144-152 \mathrm{~cm}$ where a turbidite layer occurs. The average resolution is $\sim 175$ years at a 4-cm sampling interval. Core MD403 has sedimentation rates of $50-80 \mathrm{~cm} / \mathrm{kyr}$ from $8 \mathrm{ka}$ to the present, and our 5-cm sampling interval resulted in a average temporal resolution of $\sim 70$ years per sample for the last $8 \mathrm{kyr}$. Between 8 and $11.5 \mathrm{ka}$, the sedimentation rates are $>100 \mathrm{~cm} / \mathrm{kyr}$, as resulted from the increased sediment flux in the southern Okinawa Trough when sea levels rose rapidly (Wei et al., 2005).

\subsection{Faunal analysis}

Sampling intervals for planktonic foraminiferal faunal analyses in cores MD88, OR715, and MD403
Table 1

AMS ${ }^{14} \mathrm{C}$ ages and calendar ages used in this study

\begin{tabular}{lcclc}
\hline Core & $\begin{array}{l}\text { Depth } \\
(\mathrm{cm})\end{array}$ & $\begin{array}{l}\text { AMS }{ }^{14} \mathrm{C} \text { age } \\
(\text { year BP) }\end{array}$ & $\begin{array}{l}\text { Error } \\
\text { (years) }\end{array}$ & $\begin{array}{l}\text { Calendar age } \\
\text { (year BP) }\end{array}$ \\
\hline MD982188 & 2.5 & 474 & 40 & 75 \\
& 134.5 & 2668 & 40 & 2382 \\
& 202.5 & 4913 & 35 & 5192 \\
& 278.5 & 8623 & 75 & 9266 \\
OR715-21 & 382.5 & 10991 & 55 & 12672 \\
& 5 & 407 & 40 & 0 \\
& 70.5 & 3491 & 35 & 3372 \\
& 144 & 5694 & 35 & 6094 \\
& 152 & 5752 & 35 & 6135 \\
& 164 & 6229 & 35 & 6675 \\
MD012403 & 174 & 6454 & 35 & 6957 \\
& 31.5 & 1048 & 45 & 608 \\
& 241.5 & 3244 & 45 & 3068 \\
& 371.5 & 4432 & 45 & 4625 \\
& 491.5 & 6164 & 55 & 6595 \\
& 601.5 & 8221 & 50 & 8761 \\
& 951.5 & 9553 & 70 & 10393 \\
& 1141.5 & 10312 & 45 & 11300
\end{tabular}

are approximately $8 \mathrm{~cm}, 6 \mathrm{~cm}$, and $10 \mathrm{~cm}$, respectively. The planktonic foraminifer faunal census data were made on splits of the $>149 \mu \mathrm{m}$ size fraction containing approximately 300 specimens. The taxonomy of planktonic foraminifers used in this study is primarily based on Parker (1962) and Kipp (1976), and the taxonomic conventions used for late Quaternary Western Pacific faunal records (Chen et al., 1999, 2005). We have combined three conventional taxonomical categories Neogloboquadrina pachyderma (right coiling), pachyderma-dutertrei intergrade (P-D intergrade), and $N$. dutertrei into a single unit $N$. dutertrei, for the three categories cannot be clearly distinguished. A total of 29 species were identified in this study.

\subsection{Multispecies isotopic analyses}

\subsubsection{Depth habitats of planktonic foraminifers}

Geochemical signatures from multiple species of planktonic foraminifers may reflect changes in hydrographic structure (e.g., Spero et al., 2003; Bostock et al., 2004; Rohling et al., 2004), or permit the detection of changes in depth habitat of a given species (Field, 2004). We used carbon and oxygen isotope values from a suite of planktonic foraminiferal species with different life cycles, ecologic preferences and distributions to investigate possible changes in the depth habitat of $P$. obliquiloculata and thermocline hydrography. Plankton tow data or sediment trap data in the study area are limited; only the studies by Shieh and Chen (1990), Yamasaki and Oda (2003) and Xu et al. 
(2005) provide some clues for the depth range and seasonality of species. The $300-\mu \mathrm{m}$ mesh size used in the research of Shieh and Chen (1990) was much larger than the $63-\mu \mathrm{m}$ mesh size used in recent plankton tow studies (Watkins et al., 1998; Field, 2004; Kuroyanagi and Kawahata, 2004) and therefore the inferred depth habitats from Shieh and Chen (1990) are closer to those of adult planktonic foraminifera. Data collected from sediment traps and plankton tows in other regions thus were used to infer the life habitats for different species.

G. ruber, a spinose photosymbiotic species with dinoflagellates in its protoplasm (Hemleben et al., 1989), is considered to be one of the most reliable indicators of tropical to subtropical sea surface conditions, as its habitat depth is primarily limited to the mixed layer (Ravelo and Fairbanks, 1992). In the middle Okinawa Trough, G. ruber was more abundant in warm months than during the cold seasons (Yamasaki and Oda, 2003; Xu et al., 2005). The depth habitat of $G$. ruber was estimated to be $2-50 \mathrm{~m}$ based on measured shell $\delta^{18} \mathrm{O}$ and estimated $\delta^{18} \mathrm{O}$ values (Lin et al., 2004).

N. dutertrei and Globorotalia menardii are both nonspinose species and are mainly herbivorous, but some specimens bear symbionts (Hemleben et al., 1989). These two species exhibit distribution over a large vertical extent throughout their life cycles. For example, G. menardii lives in the euphotic zone or mixed layer during juvenile stages, but then descends to the thermocline in late ontogeny (Bé and Huston, 1977; Schweitzer and Lohmann, 1991). Neoglobquadrina dutertrei seems to consist of two populations: one in tropical water masses, and the other in subtropical water masses near ocean margins (Hilbrecht, 1997). Xu et al.
(2005) reported that the seasonal flux of $N$. dutertrei in the middle Okinawa Trough is mainly controlled by the oscillation of the Kuroshio. When the Kuroshio shifted northwesterly towards the shelf area, the flux of $N$. dutertrei was lower than when under the direct influence of the Kuroshio. The preferred habitats of G. menardii and $N$. dutertre $i$ are thought to be closely associated with the chlorophyll maximum (Watkins et al., 1998; Field, 2004; Kuroyanagi and Kawahata, 2004). Although G. menardii is considered to reside within the upper to middle thermocline at depths between 25 and $85 \mathrm{~m}$ in the eastern Equatorial Pacific (Spero et al., 2003), Shieh and Chen (1990) reported that off the eastern coast of Taiwan, the abundances of both G. menardii and $N$. dutertrei increased with depth and they reached their maxima at the depth of $200 \mathrm{~m}$. We therefore regard $N$. dutertrei and $G$. menardii as middle-to-deep thermocline dwellers.

P. obliquiloculata is also a non-spinose species and a facultative symbiont bearer. It exhibits moderate vertical migration between the mixed layer and the upper thermocline during its life cycle (Hemleben et al., 1989). The preferred habitat of the species seems to be primarily associated with tropical upwelling (Watkins et al., 1996, 1998). Off the eastern coast of Taiwan, an abundance peak was observed in the upper thermocline at the station located under the main path of the Kuroshio (Shieh and Chen, 1990). Similar to $N$. dutertrei, the seasonal flux of $P$. obliquiloculata is also closely associated with the oscillation of the Kuroshio, showing higher flux under the direct influence of the Kuroshio (Xu et al., 2005). In agreement with Tian et al. (2005), we propose that $P$. obliquiloculata resides within the upper to middle thermocline in our study area; its habitat might partially overlap with that of $N$. dutertrei.

Table 2

Planktonic foraminiferal temperature $-\delta^{18} \mathrm{O}$ relationships used in this study

\begin{tabular}{|c|c|c|c|c|c|}
\hline \multirow[t]{2}{*}{ Materials } & \multirow{2}{*}{$\begin{array}{l}\text { Size } \\
(\mu \mathrm{m})\end{array}$} & \multicolumn{2}{|c|}{$T=a+b\left(\delta_{\mathrm{c}}-\delta_{\mathrm{w}}\right)$} & \multirow{2}{*}{$\begin{array}{l}\delta_{\mathrm{w}} \\
\text { correction } \\
\text { (VSMOW } \\
\text { to VPDB, } \\
\% \text { ) }\end{array}$} & \multirow[t]{2}{*}{ Reference } \\
\hline & & $a$ & $b$ & & \\
\hline G. ruber & $250-350$ & 14.9 & -4.80 & -0.27 & $\begin{array}{l}\text { Spero et al. (2003), using } \\
\text { Bemis et al. (1998) } \\
\text { equation for HL conditions }\end{array}$ \\
\hline$N$. dutertrei (plankton tow) & n.d. & 10.5 & -6.58 & -0.22 & $\begin{array}{l}\text { Bouvier-Soumagnac and } \\
\text { Duplessy (1985) }\end{array}$ \\
\hline G. menardii (culture) & $600-850$ & 14.9 & -5.13 & -0.27 & Spero et al. (2003) \\
\hline P. oblquiloculata (plankton tow) & $>500$ & 16.5 & -4.80 & -0.27 & $\begin{array}{l}\text { Russell and Spero (2000), } \\
\text { using Bemis et al. (1998) } \\
\text { equation for LL conditions }\end{array}$ \\
\hline
\end{tabular}




\subsubsection{Normalization of multispecies stable isotopic data}

We used the multispecies approach of Spero et al. (2003). The basic premise behind this approach is that variations in the isotopic composition of foraminiferal shells are primarily a function of physical properties of the water column such as temperature, salinity and $\delta^{13} \mathrm{C}$ of dissolved inorganic carbon $\left(\delta^{13} \mathrm{C}_{\mathrm{DIC}}\right)$. Isotopic signatures of multiple planktonic species with different depth preferences can be used to reconstruct thermocline structure and $\delta^{13} \mathrm{C}_{\mathrm{DIC}}$ gradient. However, the effects of disequilibrium precipitation of calcite by foraminifera on isotopes have to be corrected. The main difference between the traditional constant correction factors (Patrick and Thunell, 1997; Niebler et al., 1999) and the multispecies approach is that the latter includes temperature-dependent normalization corrections to normalize the $\delta^{18} \mathrm{O}$ using temperature- $\delta^{18} \mathrm{O}$ relationships. For the western Pacific, the foraminiferal temperature $-\delta^{18} \mathrm{O}$ correlation has not been established. We used the empirical relations from laboratory culturing and field studies from other regions, assuming that these are applicable in our study area (Table 2). For G. ruber, we used the correlation of Spero et al. (2003), because this equation gives a better estimate of the
Table 3

$\delta^{18} \mathrm{O}$ and $\delta^{13} \mathrm{C}$ normalization corrections to $\delta^{18} \mathrm{O}_{G \text {. ruber }}$ and $\delta^{13} \mathrm{C}_{\mathrm{DIC}}$ for core MD88

\begin{tabular}{|c|c|c|c|c|}
\hline \multirow[t]{2}{*}{ Species } & \multicolumn{3}{|c|}{$\delta^{18} \mathrm{O}$ normalization $(\%$ ) } & \multirow{2}{*}{$\begin{array}{l}\delta^{13} \mathrm{C} \\
\text { normalization } \\
(\% \text { o })\end{array}$} \\
\hline & at $28^{\circ} \mathrm{C}$ & at $25^{\circ} \mathrm{C}$ & at $22{ }^{\circ} \mathrm{C}$ & \\
\hline G. ruber & 0 & & & +0.94 \\
\hline P. obliquiloculata & & -0.33 & & $+0.94^{\mathrm{a}}$ \\
\hline N. dutertrei & & $0.05^{\mathrm{b}}$ & & -0.50 \\
\hline G. menardii & & & n.d. & 0 \\
\hline
\end{tabular}

${ }^{\text {a }}$ The $\delta^{13} \mathrm{C}$ normalization factor of $P$. obliquiloculata is calculated using the equation $\Delta \delta^{13} \mathrm{C}_{\text {shell-DIC }}=2.49-0.137 \mathrm{~T}$ (Russell and Spero, 2000).

${ }^{\mathrm{b}}$ The correction value applied to covert $\delta^{18} \mathrm{O}_{\mathrm{w}}$ values from the VSMOW to VPDB scales in Bouvier-Soumagnac and Duplessy (1985) is $-0.22 \%$, which is $0.05 \%$ higher than the current adopted value of $-0.27 \%$. The $0.05 \%$ offset is included in our calculation.

surface water $\delta^{18} \mathrm{O}$ (see below). Lin et al. (2004) demonstrated that the $G$. ruber $\delta^{18} \mathrm{O}$-temperature correlation in the northern SCS is more consistent with the values calculated based on Mulitza et al. (2003), we found that the application of either equation yields similar results in the reconstructed vertical hydrography. We applied the equation of BouvierSoumagnac and Duplessy (1985) for $N$. dutertrei, since
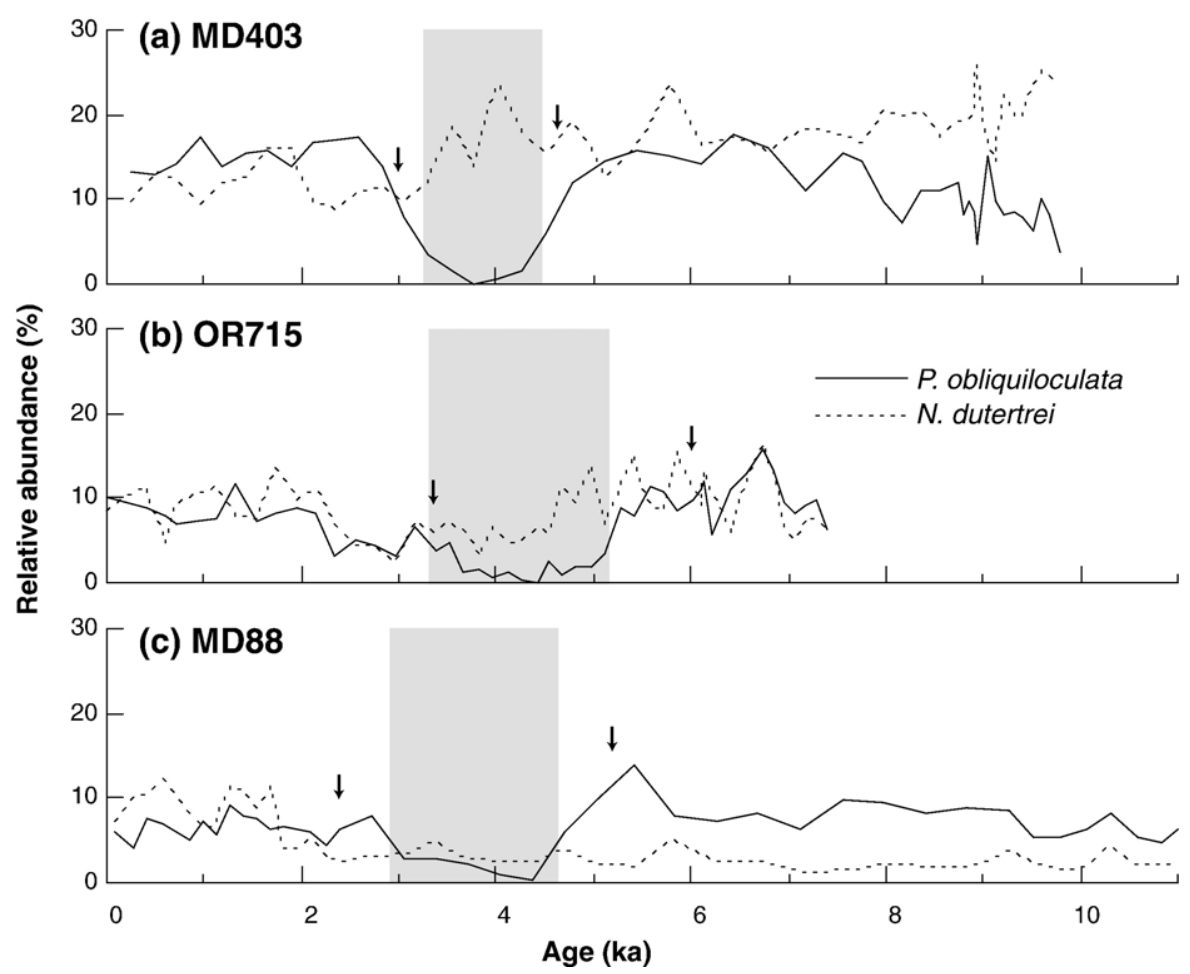

Fig. 4. Relative abundances of P. obliquiloculata (solid line) and $N$. dutertrei (dash line) in (a) MD403, (b) OR715 and (c) MD88. The PME period is shaded. Arrows indicate the ${ }^{14} \mathrm{C}$ data bracketing the PME period. 
no new equation has been published. We used the equation of Spero et al. (2003) for G. menardii, as this experiment-derived relationship is indistinguishable from the plankton tow based relationship (BouvierSoumagnac and Duplessy, 1985). Although P. obliquiloculata is a species rarely used in isotopic analyses, we followed Russell and Spero (2000), who applied the low-light (LL) temperature- $\delta^{18} \mathrm{O}$ relationship of $O$. universa (Bemis et al., 1998) to P. obliquiloculata data and found an acceptable correlation between observed and estimated temperatures $\left(R^{2}=0.77, n=6\right)$. Based on the temperature profiles in Fig. $4 \mathrm{a}$, we estimated the mean temperatures at depth of the mixed layer, the middle thermocline and the deep thermocline at sites MD88 and MD403. The final results of the $\delta^{18} \mathrm{O}$ normalization factors to $G$. ruber $\delta^{18} \mathrm{O}$ are listed in Tables 3 and 4. The difference in VSMOW to VPDB corrections among the four empirical relationships (Coplen et al., 1983; Hut, 1987) was adjusted.

Foraminiferal $\delta^{13} \mathrm{C}$ is controlled by several factors, including the $\delta^{13} \mathrm{C}_{\text {DIC }}$ (Kroopnick, 1985; Spero, 1992), vital effects (Spero and Williams, 1988), carbonate ion effects (Spero et al., 1997; Russell and Spero, 2000), temperature (Bemis et al., 2000), and dissolution (Berger and Killingley, 1977). For G. ruber, N. dutertrei and $G$. menardii, we applied the constant normalization factors used in Spero et al. (2003) (Tables 3, 4). The $\Delta \delta \delta^{13} \mathrm{C}_{\text {shell-DIC }}$ offset of $-0.94 \pm 0.28 \%$ o for $G$. ruber based on plankton tow data collected from the tropical Atlantic and northern Caribbean is not significantly different from the $\Delta \delta^{13} \mathrm{C}_{\text {shell-DIC }}$ of $-0.84 \pm 0.25 \%$ $(n=8)$ established using sediment trap data from the northern SCS (Lin et al., 1999, 2004). We did not apply any temperature correction to the $\delta^{13} \mathrm{C}$ normalization factors for $G$. ruber, $N$. dutertrei and $G$. menardii

Table 4

$\delta^{18} \mathrm{O}$ and $\delta^{13} \mathrm{C}$ normalization corrections to $\delta^{18} \mathrm{O}_{G .}$ ruber and $\delta^{18} \mathrm{O}_{\mathrm{DIC}}$ for core MD403

\begin{tabular}{|c|c|c|c|c|}
\hline \multirow[t]{2}{*}{ Species } & \multicolumn{3}{|c|}{$\delta^{18} \mathrm{O}$ normalization $(\% \mathrm{o})$} & \multirow{2}{*}{$\begin{array}{l}\delta^{13} \mathrm{C} \\
\text { normalization } \\
(\%)\end{array}$} \\
\hline & at $25^{\circ} \mathrm{C}$ & at $22{ }^{\circ} \mathrm{C}$ & at $20^{\circ} \mathrm{C}$ & \\
\hline G. ruber & 0 & & & +0.94 \\
\hline P. obliquiloculata & & -0.33 & & $+0.53^{\mathrm{a}}$ \\
\hline N. dutertrei & & $+0.22^{\mathrm{b}}$ & & -0.50 \\
\hline G. menardii & & & -0.07 & 0 \\
\hline
\end{tabular}

${ }^{\text {a }}$ The $\delta^{13} \mathrm{C}$ normalization factor of $P$. obliquiloculata is calculated using the equation $\Delta \delta^{13} \mathrm{C}_{\text {shell-DIC }}=2.49-0.137 \mathrm{~T}$ (Russell and Spero, 2000).

${ }^{\mathrm{b}}$ The correction value applied to covert $\delta^{18} \mathrm{O}_{\mathrm{w}}$ values from the VSMOW to VPDB scales in Bouvier-Soumagnac and Duplessy (1985) is $-0.22 \%$, which is $0.05 \%$ o higher than the current adopted value of $-0.27 \%$. The $0.05 \%$ offset is included in our calculation. because no temperature- $\delta{ }^{13} \mathrm{C}$ relationship is available. For P. obliquiloculata, Russell and Spero (2000) found that its $\Delta \delta^{13} \mathrm{C}_{\text {shell-DIC }}$ and $\delta^{13} \mathrm{C}_{\text {DIC }}$ display a strong negative linear relationship $\left(\Delta \delta^{13} \mathrm{C}_{\text {shell-DIC }}=2.49\right.$ $\left.0.137 \mathrm{~T}, R^{2}=0.82, P=0.01\right)$, implying that isotopically light metabolic carbon is preferentially incorporated under higher temperatures. We therefore applied this equation to calculate the normalization factors for $P$. obliquiloculata.

\subsubsection{Downcore analysis}

For stable oxygen and carbon isotopic analyses, $G$. ruber was used at every 4-cm interval in cores MD88 and OR715, and every $5 \mathrm{~cm}$ in core MD403. The other three species were sampled every $4 \mathrm{~cm}$ in MD88 and $10 \mathrm{~cm}$ in MD403. G. ruber (white) were picked from the 250 - to $355-\mu \mathrm{m}$ size fraction, $N$. dutertrei from the $355-$ to $425-\mu \mathrm{m}$ size fraction, and $G$. menardii and $P$. obliquiloculata from the $>425 \mu \mathrm{m}$ size fraction. $G$. ruber is known to have two morphotypes, G. ruber sensu stricto (s.s.) and G. ruber sensu lato (s.1.). We picked $G$. ruber s.s. because its habitat is closer to sea surface than G. ruber s.l. (Wang, 2000; Löwemark et al., 2005; Steinke et al., 2005). N. dutertrei and G. menardii are reported to add a calcite crust of varying amounts that can shift the isotopic composition toward deeper, colder environments (Hemleben et al., 1989). We visually identified and selected specimens with minimal crustation for analysis. We picked specimens of $P$. obliquiloculata with shiny cortex in order to be consistent with the morphological criterion used in Russell and Spero (2000).

Six to eight shells of $G$. ruber were required to give a total sample weight of $80-100 \mu \mathrm{g}$ for isotope analysis, while $N$. dutertrei, G. menardii and $P$. obliquiloculata samples were made up of 2-5 individuals to achieve the required weight. Samples were immersed in $\mathrm{CH}_{3} \mathrm{OH}$ and subjected to ultrasonic vibration for 6 seconds three times to remove clay particles. After removing methanol, they were immersed in $\mathrm{NaOCl}$ for 24 hours to remove organic matter. After being cleaned by deionized water five times and dried, specimens from core MD88 were measured using the Finnigan MAT Delta ${ }^{\text {plus }}$ mass spectrometer with a Kiel Device at the Department of Geosciences, National Taiwan University, while samples from cores OR715 and MD403 were measured using the Micromass Isoprime isotope ratio mass spectrometer housed at the Department of Earth Sciences, National Taiwan Normal University. All $\delta^{18} \mathrm{O}$ and $\delta^{13} \mathrm{C}$ values are reported vs. the Pee Dee Belemnite scale. External precision was 
better than $0.10 \%$ and $0.06 \% 0( \pm 1 \sigma)$ for $\delta^{18} \mathrm{O}$ and $\delta^{13} \mathrm{C}$, respectively, based on repeated analyses of the internal laboratory standard. Thirty samples from core MD403 were repicked and rerun for duplication test of $\delta^{18} \mathrm{O}$. One standard deviation of the difference of $\delta^{18} \mathrm{O}$ between duplicates is $\sim 0.17 \%$.

\section{3. $\mathrm{Mg} / \mathrm{Ca}$ ratio measurement}

To estimate SST using a method independent of the faunal composition, we measured the $\mathrm{Mg} / \mathrm{Ca}$ values of planktonic foraminifera in core MD403. Approximately 20 individuals of $G$. ruber, $250-355 \mu \mathrm{m}$ in size, were picked from the $1-\mathrm{cm}$ slice adjacent to the sample slice from which the specimens for isotope analysis had been picked. Although the isotope and $\mathrm{Mg} / \mathrm{Ca}$ samples were not exact 'paired samples', we assumed that bioturbation had homogenized these two adjacent layers to certain degree, so that the $\delta^{18} \mathrm{O}$ and $\mathrm{Mg} / \mathrm{Ca}$ values can be combined to calculate $\delta^{18} \mathrm{O}$ of seawater $\left(\delta^{18} \mathrm{O}_{\mathrm{sw}}\right)$. The $\mathrm{Mg} / \mathrm{Ca}$ samples were processed following a cleaning procedure modified from Shen et al. (2001). First, shells were gently crushed using two ethanol-cleaned glass plates, making sure that all chambers were fully opened. Samples were then leached sequentially in an ultrasonic bath using four reagents designed to remove attached fine clays, organics, chemically exchangeable contaminants, and hydrogenous metal oxides, respectively. The sequence of the four reagents was: (1) ethanol, (2) $1 \% \mathrm{H}_{2} \mathrm{O}_{2}$ at $\mathrm{pH} \mathrm{8-8.5,} \mathrm{(3)} 1.0 \mathrm{M} \mathrm{NH}_{4} \mathrm{Cl}$ and (4) $0.01 \mathrm{M} \mathrm{NH}_{2} \mathrm{OH}$, which was prepared from hydroxylamine- $\mathrm{HCl}$. After leaching with $0.5 \times 10^{-3} \mathrm{M} \mathrm{HNO}_{3}$ for $5 \mathrm{~min}$, the samples were dissolved completely in $1 \% \mathrm{HNO}_{3}$. The $\mathrm{Mg} / \mathrm{Ca}$ ratio was determined on a quadrupole inductively coupled plasma mass spectrometer (QICPMS, Agilent 7500) at the Department of Geosciences, National Taiwan University. Details of the instrumental analysis were described in Shen et al. (2004). Analyses of the $\mathrm{Mg} / \mathrm{Ca}$ working standard showed that the long-term precision was $0.5 \%(1 \sigma)$ for $\mathrm{Mg} / \mathrm{Ca}$ during our measurement period. Fifteen samples were repicked and rerun. One standard deviation of the difference of these analyses is $\sim 0.22 \mathrm{mmol} / \mathrm{mol}$, or $0.38{ }^{\circ} \mathrm{C}$. We conservatively estimated the total error to be equivalent to $\sim \pm 0.5{ }^{\circ} \mathrm{C}$ $(1 \sigma)$. The G. ruber $\mathrm{Mg} / \mathrm{Ca}$ values were converted to SST using the equation developed from South China Sea core-top sediments: $\mathrm{SST}=\ln (\mathrm{Mg} / \mathrm{Ca} / 0.38) / 0.089$ (Hastings et al., 2001). Random error in $\delta^{18} \mathrm{O}_{\mathrm{sw}}$, propagated from errors in $\delta^{18} \mathrm{O}$ and $\mathrm{Mg} / \mathrm{Ca}$-derived SST, is $\sim 0.19 \%$.

\section{Results and discussion}

\subsection{Planktonic foraminiferal assemblages}

To identify the PME more precisely, we defined the PME as a period in which the relative abundance of $P$. obliquiloculata is continuously lower than $5 \%$. According to the definition, all the three cores record the PME (Fig. 4). The timing of the minimum zone seems to agree well in cores MD88 and MD403 based upon ${ }^{14} \mathrm{C}$ dating, but the starting point is about 500 years earlier in core OR715. The apparent heterochroneity may be the result of lack of age control: ages are not well constrained by ${ }^{14} \mathrm{C}$ data for the $5-4$ ka interval in core OR715. Therefore, we followed the previous report that the PME occurred from $\sim 4500$ to 3000 year BP (Ujiié et al., 2003a).

The occurrence of the PME at site MD88 in the neighborhood of the North Equatorial Current bifurcation point supports the argument of Ujiié et al. (2003a) that the PME may have originated in the equatorial Pacific and propagated westward and northward through the North Equatorial Current-Kuroshio system. However, their argument that the low abundance of $P$. obliquiloculata in the western North Pacific is linked to ENSO activity in the remote equatorial Pacific (Ujiie et al., 2003a) remains to be tested. These authors assume that $P$. obliquiloculata is mainly transported from the equatorial area to higher latitudes via the Kuroshio, which is not supported by a transit time from central Equatorial Pacific to the southern Okinawa Trough of approximately 6 years as estimated by Lee et al. (2004). Such a transit time would have allowed the population of $P$. obliquiloculata to respond to local hydrography rather than to reflect remote oceanographic conditions.

The negative correlation of the relative abundances of P. obliquiloculata and N. dutertrei in core MD403 agrees well with previous records (Ujiié et al., 2003a), but is less prominent in core OR715 and absent in core MD88 (Fig. 4). The warm, well-stratified and oligotrophic waters at the MD88 core site may account for the low abundance of $N$. dutertrei, which prefers cooler and more eutrophic waters (Yamasaki and Oda, 2003). $N$. dutertrei is considered characteristic of both Kuroshio water (Ujiié and Ujiié, 2000) and gyremargin assemblages (Thompson, 1981). Ujiié et al. (2003a) argued that the high abundance of $N$. dutertrei in the Okinawa Trough during the PME implied a weakened Kuroshio under El Niño-like conditions, which in turn led to the thriving of $N$. dutertrei as a gyre-margin water indicator. However, according to $\mathrm{Xu}$ et al. (2005), during the period when the Kuroshio axis 


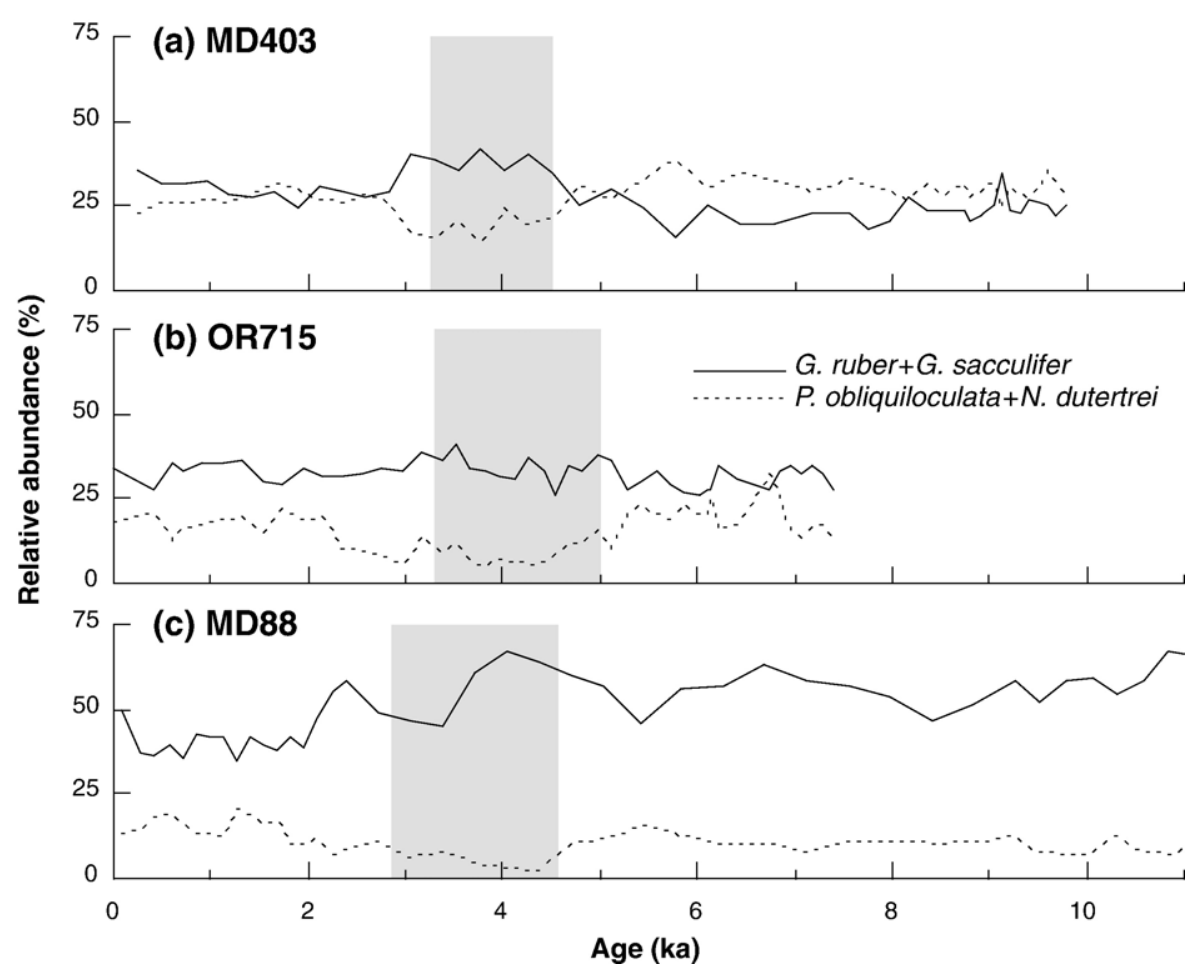

Fig. 5. Relative abundances of G. ruber + G. sacculifer (solid line) and P. obliquiloculata $+N$. dutertrei (dash line) during the Holocene. The PME period is shaded.
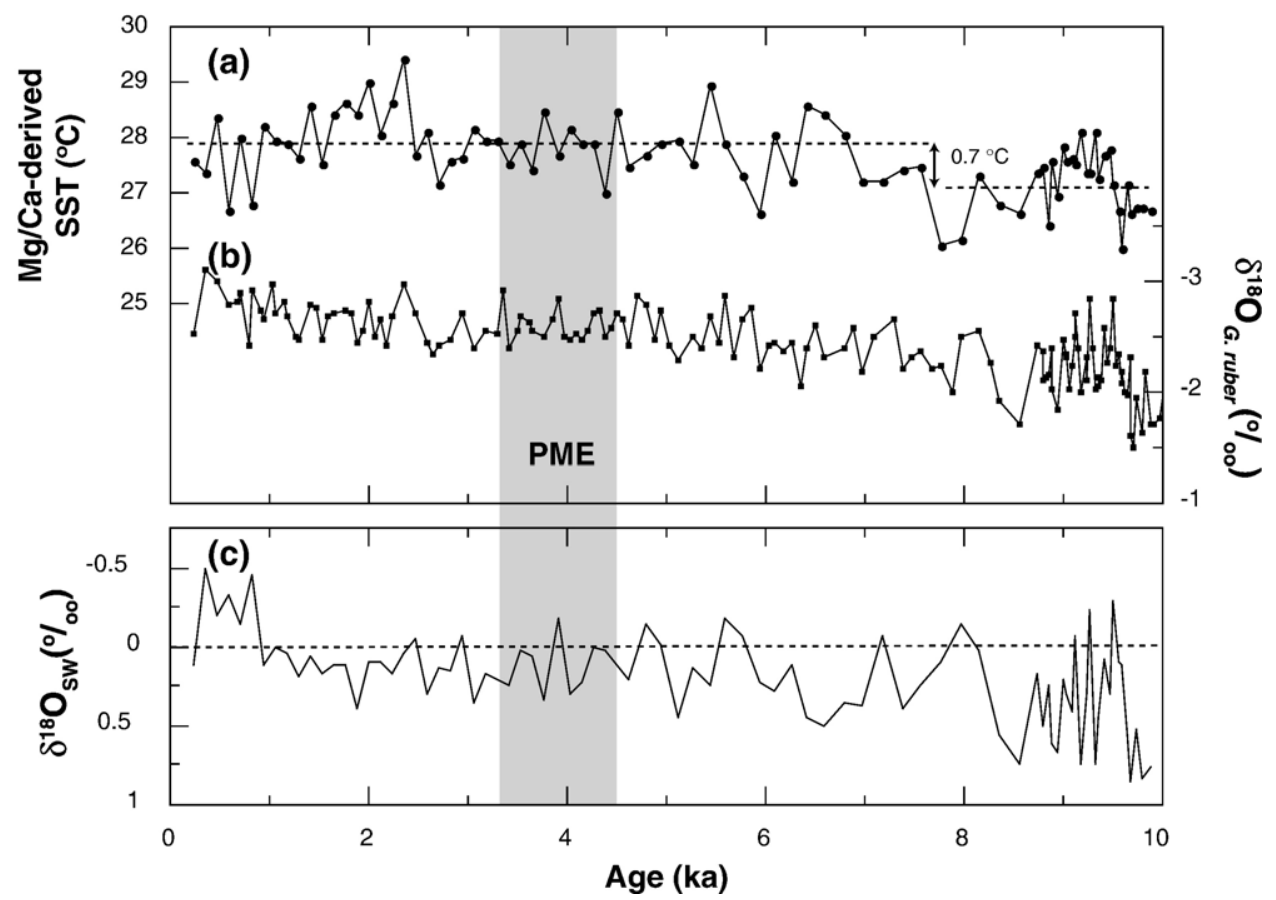

Fig. 6. SST and SSS estimates of MD403. (a) G. ruber Mg/Ca-derived SST. (b) G. ruber $\delta^{18} \mathrm{O}$. (c) The calculated $\delta^{18} \mathrm{O}$ of seawater. 
shifted northwestwards and the middle Okinawa Trough was under higher influence of gyre-margin water, the flux of $N$. dutertrei did not increase but decreased simultaneously with that of $P$. obliquiloculata. The diets of both species consist mainly of diatoms (Hemleben et al., 1989), so it is probable that even without paleoceanographic changes during the PME, $N$. dutertrei could thrive in the Okinawa Trough because it enjoyed a higher food supply in the absence of competition by $P$. obliquiloculata.

These faunal data can also be used to evaluate the paleoceanographic connections between the upper reaches of the Kuroshio and the Okinawa Trough. The time-series of the relative abundances of four species ( $G$. ruber, G. sacculifer, P. obliquiloculata, $N$. dutertrei) in our study area (Fig. 5) show that the difference between the relative abundances of $G$. ruber $+G$. sacculifer and $P$. obliquiloculata $+N$. dutertrei decreases northward. This transition implies that the planktonic foraminiferal assemblage in the Okinawa Trough does not merely reflect the signal of the warm, saline, oligotrophic
Kuroshio water, but records a modified signal modulated by the processes in the Okinawa Trough.

\subsection{SST and SSS in the southern Okinawa Trough}

The Holocene record of foraminiferal $\mathrm{Mg} / \mathrm{Ca}$ in the southern Okinawa Trough shows moderate variability (Fig. 6a). The core-top measurement yields a temperature of $27.6{ }^{\circ} \mathrm{C}$, which is close to the present-day average SST during May to October $\left(27.3{ }^{\circ} \mathrm{C}\right.$; Levitus and Boyer, 1994). Accordingly, we consider the $G$. ruber $\mathrm{Mg} / \mathrm{Ca}$-derived temperatures to represent the average SST of warm seasons. The mean $\mathrm{Mg} / \mathrm{Ca}-$ based SST during the early Holocene (10-8 ka) is $\sim 27.1{ }^{\circ} \mathrm{C}, \sim 0.7{ }^{\circ} \mathrm{C}$ lower than the average SST from $8 \mathrm{ka}$ to present. Details of the $\mathrm{Mg} / \mathrm{Ca}$ data are discussed elsewhere (Lin, 2005) and here we only focus on the PME period.

We firstly tested the 'cooling hypothesis' proposed by Jian et al. (2000). During the PME period, the average SST is $27.9 \pm 0.4{ }^{\circ} \mathrm{C}$, not significantly different
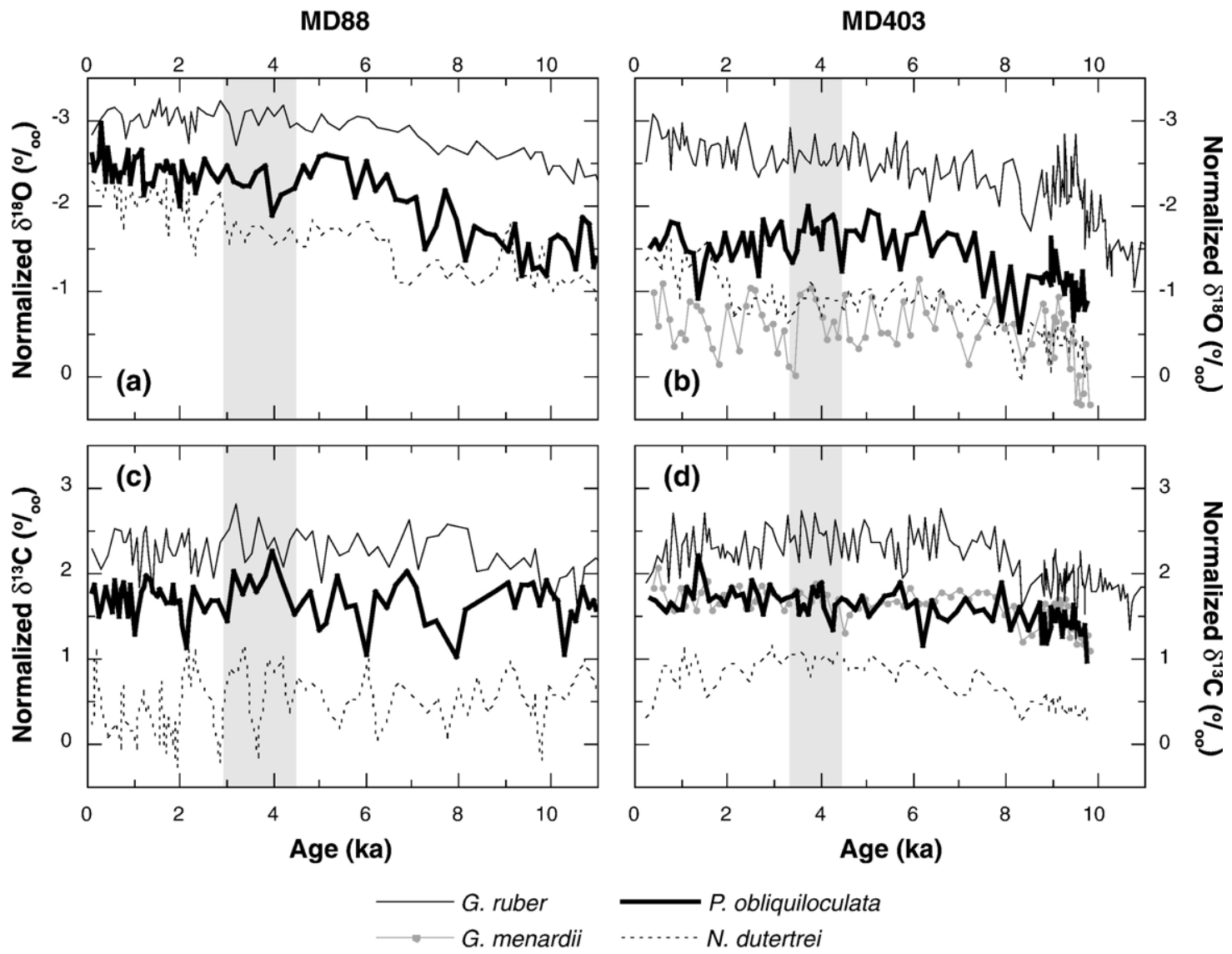

Fig. 7. Results of the multispecies isotopic analyses. (a)(b) Oxygen and (c)(d) carbon isotope data of G. ruber, P. obliquiloculata, N. dutertrei and G. menardii normalized to $\delta^{18} \mathrm{O}_{G \text {. ruber }}$ and $\delta^{13} \mathrm{C}_{\mathrm{DIC}}$, respectively. The PME period is shaded. 
from the average SSTs during $6-4.5 \mathrm{ka}\left(27.7 \pm 0.6{ }^{\circ} \mathrm{C}\right)$ and 3-2.5 $\mathrm{ka}\left(27.8 \pm 0.4{ }^{\circ} \mathrm{C}\right)$. A $\mathrm{Mg} / \mathrm{Ca}$-derived SST record from the middle Okinawa Trough also does not display cooling during the PME (Sun et al., 2005). These $\mathrm{Mg} / \mathrm{Ca}$-derived SST records thus confirm the arguments of Li et al. (2001) and Ujiié et al. (2003a), who rejected cooling during the PME because they did not observe changes in planktonic $\delta^{18} \mathrm{O}$ values.

Ujiié et al. (2003a) argued that during the El Niñolike conditions, the weakened Kuroshio transport would result in an increase in relative abundance of $N$. dutertrei, along with other species characteristics of the coastal water assemblage throughout the Okinawa Trough. Such an increase in coastal water assemblage species should be accompanied by lowered SSS. We calculated the $\delta^{18} \mathrm{O}_{\mathrm{sw}}$ by subtracting the temperature effect from the $G$. ruber $\delta^{18} \mathrm{O}$ values using the temperature $-\delta^{18} \mathrm{O}$ relationship of Spero et al. (2003). The calculated core-top $\delta^{18} \mathrm{O}_{\mathrm{sw}}$ is $0.11 \%$ (Fig. 6c), within the range of $\delta^{18} \mathrm{O}_{\mathrm{sw}}$ values $(0.18 \pm 0.19 \%)$ measured in surface water samples near the core site during summer. The MD403 $\delta^{18} \mathrm{O}_{\mathrm{sw}}$ record displays a long-term decrease in variability. The $\delta^{18} \mathrm{O}_{\mathrm{sw}}$ values during the early Holocene oscillate from $0.7 \%$ to $-0.2 \%$, but the magnitudes of oscillation decrease to $\sim 0.5 \%$ in the mid Holocene and $\sim 0.2 \%$ during $2-1 \mathrm{ka}$. During the PME, the $\delta^{18} \mathrm{O}_{\mathrm{sw}}$ values did not deviate from the generally decreasing trend in variability. Other than that, our evidence does not support that surface waters became less saline at the location of core MD403 during the PME.

In addition, the PME has been recorded in the southern SCS (Fig. 1) where no SSS front between salty and fresh waters exists. Therefore, it is unlikely that the PME was related to changes in SSS in these two marginal seas.

\subsection{Thermocline hydrography}

The normalized multispecies $\delta^{18} \mathrm{O}$ records for cores MD88 and MD403 are shown in Fig. 7a and b. We did not measure the isotopes of G. menardii in core MD88 because of its scarcity throughout the Holocene. In both records, these species show a clear and consistent depth ranking in which G. ruber registered the lowest $\delta^{18} \mathrm{O}$ values indicating the shallowest habitat. P. obliquiloculata had more negative $\delta^{18} \mathrm{O}$ values than $N$. dutertrei during the early to middle Holocene, but the $\delta^{18} \mathrm{O}$ values converged at $2 \mathrm{ka}$ in both sequences. In core MD403, G. menardii and $N$. dutertrei have similar $\delta^{18} \mathrm{O}$ values, but the $\delta^{18} \mathrm{O}$ record of $G$. menardii displays higher variability, suggesting either a larger vertical migration depth range, or random errors due to the low number of specimens (2-3 individuals) used in measurements. The $\delta^{18} \mathrm{O}$ values in core MD88 are generally more negative than those in core MD403, as a reflection of the warmer environment in the western Philippine Sea (Fig. 3).

From $8 \mathrm{ka}$ to the present, the $\delta^{18} \mathrm{O}$ records of $G$. ruber, $P$. obliquiloculata and $N$. dutertrei all display a long-term decreasing trend, more prominent in the MD88 record than in the MD403 record (Fig. 7). Shared variability in signatures of all species would likely reflect real changes in temperature and/or salinity within the thermocline (Field, 2004). Therefore, it is likely that the waters in the upper reaches of the Kuroshio became progressively warmer and/or less saline in the period, but such a signal was somewhat modified by complex hydrographic processes in the southern Okinawa Trough. Ujiié et al. (2003b) reported more positive $\delta^{18} \mathrm{O}$ values of $P$. obliquiloculata and $N$. dutertrei in the Okinawa Trough during the PME. In the MD88 and MD403 records, there are consistent differences in $\delta^{18} \mathrm{O}$ values of $P$. obliquiloculata and the other three species from 8 to $2 \mathrm{ka}$, but without any excursions during the PME, implying that the thermocline conditions did not change abruptly, or that the relationship between the depth habitats of P. obliquiloculata and $N$. dutertrei did not change. After $2 \mathrm{ka}$, the $\delta^{18} \mathrm{O}$ values of $N$. dutertrei became more negative by $\sim 0.5 \%$ in both cores, implying a smaller temperature gradient within the upper to middle thermocline or a change in the depth habitat of $N$. dutertrei.

The subsurface nutrient condition was examined using the $\delta^{13} \mathrm{C}$ records. The multispecies $\delta^{13} \mathrm{C}$ values normalized to $\delta^{13} \mathrm{C}_{\text {DIC }}$ show a similar pattern of depth ranking as the normalized $\delta^{18} \mathrm{O}$ records (Fig. 7c, d). G. ruber, the shallowest dwelling species, yields a $\delta^{13} \mathrm{C}$ of $\sim 2 \%$ before $8 \mathrm{ka}$ and $\sim 2.5 \%$ after $8 \mathrm{ka}$. $P$. obliquiloculata records $\delta^{13} \mathrm{C}$ values representing either the lower mixed layer or upper thermocline conditions. $N$. dutertrei has the most negative $\delta^{13} \mathrm{C}$ values, in agreement with its deeper habitat. The G. menardii values are close to those of $P$. obliquiloculata, implying similar habitat depths of both species as to nutrient gradient, but, the $\delta^{18} \mathrm{O}$ records suggest a deeper habitat for G. menardii (Fig. 7b). We attribute this inconsistency to either incorrect estimation of habitat depth or the use of an inappropriate normalization factor. Despite this inconsistency in the depth ranking between the $\delta^{18} \mathrm{O}$ and $\delta^{13} \mathrm{C}$ records, the isotopic values of $G$. menardii do not show an excursion during the PME, supporting our interpretation that there is no change in thermocline hydrography during the PME. 
We interpreted the normalized $\delta^{13} \mathrm{C}$ variations as indications of change in $\delta^{13} \mathrm{C}_{\text {DIC }}$ or vertical migration of planktonic foraminifers within the chemocline. A remarkable feature in both sequences is the $\sim 0.5 \%$ o difference in $\delta^{13} \mathrm{C}$ values before and after $8 \mathrm{ka}$. Such a shift at $8 \mathrm{ka}$ was also observed in the northern Okinawa Trough (Jian et al., 2000; Ijiri et al., 2005) and southern SCS (Stephan Steinke, personal communication, 2005), but the reason for this post-deglacial $\delta^{13} \mathrm{C}$ shift is unclear. The $\delta^{13} \mathrm{C}$ values of $P$. obliquiloculata in the MD88 shifted closer to $G$. ruber surface values by $\sim 0.3 \%$. The decreased difference between $\delta^{13} \mathrm{C}$ values of P. obliquiloculata and surface species was also documented in some cores from the Okinawa Trough (Ujiié et al., 2003b), but not in the MD403 record. Ujiié et al. (2003b) interpreted the decreased $\Delta \delta^{13} \mathrm{C}$ between the surface and thermocline dwellers as evidence for a shoaling thermocline due to a weaker Kuroshio transport, but the $\delta^{18} \mathrm{O}$ data do not support such a change in habitat of $P$. obliquiloculata toward shallower depth during the PME in core MD88. The $\delta^{13} \mathrm{C}_{\text {DIC }}$ transition zone occurs within a narrow depth range in the upper pycnocline (Fairbanks et al., 1982), so the $\delta^{13} \mathrm{C}$ shift could be the result of a small change in $P$.
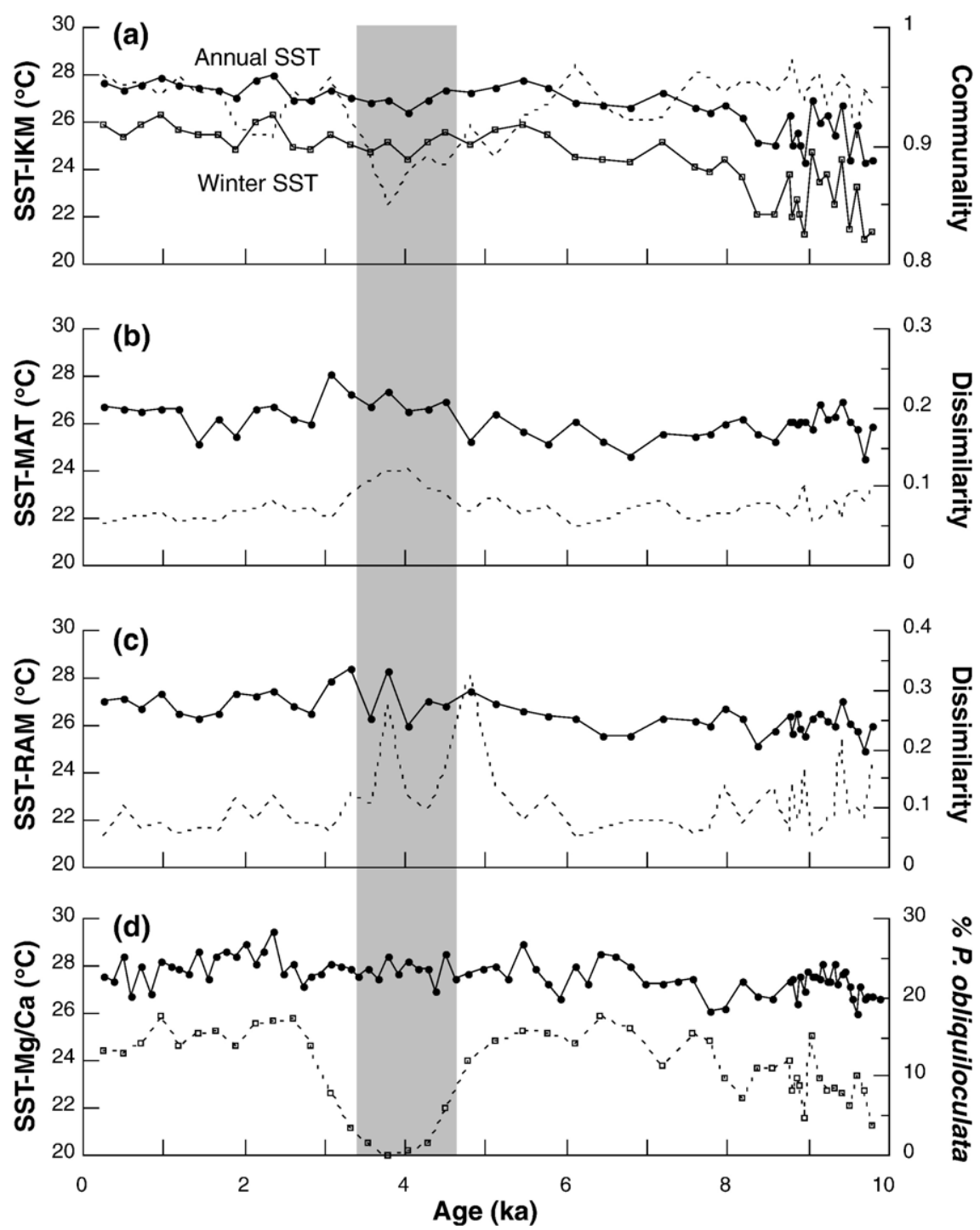

Fig. 8. Comparison of three SST reconstructions based on planktonic foraminifer counts in core MD403. (a) IKM: Imbrie-Kipp method; (b) MAT: modern analog technique; (c) RAM: revised analog method. The dash lines denote the communality or dissimilarity of each SST reconstruction. (d) The G. ruber Mg/Ca-derived SST (solid line) and relative abundance of P. obliquiloculata (dash line). The PME period is shaded. Data and method for these reconstructions are from Chen et al. (2005). 
obliquiloculata habitat depth within the upper thermocline or merely a shift in depth of the $\delta^{13} \mathrm{C}_{\mathrm{DIC}}$ chemocline associated with subtle changes in the structure of the pycnocline (Loubere, 2001). Not observed in other sites during the PME, such a slight change in subsurface nutrient condition at MD88 is more likely to be a local phenomenon rather than a widespread event that would result in the reduction of $P$. obliquiloculata populations.

\subsection{On the PME and ENSO}

Existing paleoenvironmental hypotheses (Li et al., 1997; Cheng and Wang, 1998; Ujiié and Ujiié, 1999; Jian et al., 2000) were not supported by the evidence in this study. A common feature in these hypotheses is their 'marginal-sea' point of view. In contrast, the Ujiié et al. (2003a) hypothesis pointed out for the first time the possible relationship between the PME and the equatorial Pacific, and their suggestion of the existence of El Niño-like conditions during the PME deserves further discussion.

The long-term variability of Holocene ENSO-like events is debated vigorously among climate modelers and paleoclimatologists. Data from Peruvian archaeological deposits suggest that the eastern equatorial Pacific was relatively warmer during the middle Holocene, indicating El Niño-like conditions (Sandweiss et al., 1996; Andrus et al., 2002). Various lines of evidence suggest the occurrence of more La Niña-like conditions during the early Holocene (Clement et al., 2000; Koutavas et al., 2002; Moy et al., 2002). It would be consistent with the hypothesis that ENSO conditions became enhanced after the middle Holocene if the PME could be seen as a proxy signal for El Niño (Ujiié et al., 2003a). However, the PME did not persist long enough into the late Holocene, when ENSO became further strengthened after $3 \mathrm{ka}$ (Moy et al., 2002; Rein et al., 2005). Unusual conditions at $\sim 4.2 \mathrm{ka}$ (Hong et al., 2005) were interpreted as a 'super El Niño', with a timing coincident with that of the PME. The record by Hong et al. (2005), however, does not agree with the interpretation of the interval of $3.7-4.5 \mathrm{ka}$ as a 'quiescent' ENSO period (Moy et al., 2002), supported by marine records which display no sign of a strong El Niño during 4.5-3 ka (Rein et al., 2005). As long as there is no agreement on the reconstructions of the strength of El Niño conditions in the past, we cannot interpret the PME in terms of El Niño strength. In summary, the cause of the PME remains enigmatic and requires further study. The factors controlling variability in relative abundance of planktonic foraminiferal species at millennial timescales are not yet understood and may be difficult to gauge with presently available paleoceanographic proxies.

\subsection{Implications for fauna-based paleoceanographic reconstructions}

The most fundamental assumption of fauna-based paleoceanographic reconstructions is the dominant control of environmental factors on the abundance one single species or on the whole assemblage. In the case of the Holocene PME, the species considered to be a 'Kuroshio indicator' suddenly decreased in abundance, but there are no corresponding anomalies in isotope and trace element proxies. Such a discrepancy has profound implications for the applicability and methodology of the fauna-based techniques. To demonstrate the influence of the PME on the applicability of fauna-based paleothermometers, we present a comparison of three SST reconstructions derived from the Imbrie-Kipp method (IKM), the modern analog technique (MAT), and the revised analog method (RAM) based upon the faunal census data in MD403 (Fig. 8), using techniques and a calibration database as in Chen et al. (2005) and Kucera et al. (2005).

In contrast to a decreased winter SST in the Okinawa Trough as estimated by the FP-12E transfer functions (Jian et al., 2000), we were surprised to see that none of the fauna-based SSTs decreased during the PME period. The discrepancy between the SST reconstructions of FP12E (Jian et al., 2000) and IKM may be due to the use of the more recent planktonic foraminifer databases. The MAT-derived SSTs increased slightly during about 5$3 \mathrm{ka}$, but the magnitude of the increase is within the uncertainties of $\sim 1{ }^{\circ} \mathrm{C}$ (Chen et al., 2005). The reliability of all three SST estimates decreases for the PME interval, as indicated by the lowered communality values for the IKM and increased dissimilarities for the MAT and RAM (Fig. 8). The locations of the identified analogous faunas in the MAT and RAM during the PME are in the northern SCS and in the western equatorial Pacific, respectively. The selection of these tropical sites as analogs might be due to the increased relative abundance of warm water species, e.g., G. ruber, during the PME in MD403 (Fig. 5). The PME, therefore, makes the fauna-based paleothermometers potentially less trustworthy.

The assumption of that one environmental factor (e.g., temperature or nutrients) dominates the life history of planktonic species has been a fundamental basis of fauna-based techniques. This presumption may cause misleading results for paleoceanographic 
reconstructions. For example, in the case of the PME, one consequence is the eagerness to attribute the faunal change to an environmental cause, and, in some cases, leading to circular reasoning. None of the previous environmental explanations for the PME were supported by our data: an abrupt change in fauna is not necessarily equivalent to an abrupt environmental change. What we need is to know more about the organisms in the present ocean as well as in the past.

\section{Conclusions}

We evaluated several explanations for the Holocene Pulleniatina Minimum Event (PME) using deep-sea cores with a wide geographic coverage and new paleoceanographic proxies, including $\mathrm{Mg} / \mathrm{Ca}$ values and multispecies isotopic analyses. Our data indicate that the PME was a widespread paleoecological event in the western North Pacific, but no marked anomalies in conventional paleoceanographic proxies can be identified to account for the catastrophic reduction of $P$. obliquiloculata between 4.5 and $3 \mathrm{ka}$. The proposed different preferences for ocean fertility, resulting in opposite patterns in relative abundance of $P$. obliquiloculata and $N$. dutertrei during a weaker Kuroshio and an El Nino-like condition, is not supported by our multispecies isotope data. The cause of the PME thus remains enigmatic and requires further study. Our evidence indicates that fauna-based reconstructions of SST are not very reliable, at least during some periods such as the PME, implying that the presumed relations between faunal parameters and physical environmental factors was variable, even during such a short time period as the Holocene.

\section{Acknowledgements}

The critical reviews and comments by Dr. D. Schmidt, one anonymous reviewer and Dr. E. Thomas significantly improved this manuscript. The suggestions given by Drs. M.-T. Chen, S.-J. Kao and L. Löwenmark are highly appreciated. We are grateful to Prof. S.-L. Chung for sharing the Q-ICPMS facilities with us, Y.-P. Chang for guidance during the planktonic foraminiferal assemblage analysis, L. Lo for helping with the $\mathrm{Mg} / \mathrm{Ca}$ measurements, and N.Y. Lin for assistance on GMT operation. We acknowledge Dr. H.-L. Lin for insightful discussions on the ecology of planktonic foraminifera. We express our appreciation to the captain and crews of RV Marion Dufresne for obtaining cores MD01-2403 and MD98-2188, and Dr. C.-A. Huh and the captain and crews of OR I for providing core OR715-21. This study was funded by the NSC grant NSC93-2611-M-002-010 to KYW, and graduate fellowships awarded to YSL by CTCI Foundation and Archilife Research Foundation.

\section{References}

Andrus, C.F.T., Crowe, D.E., Sandweiss, D.H., Reitz, E.J., Romanek, C.S., 2002. Otolith $\delta^{18} \mathrm{O}$ record of mid-Holocene sea surface temperatures in Peru. Science 295, 1508-1511.

Bé, A.W.H., 1977. An ecological, zoogeographical and taxonomic review of recent planktonic foraminifera. In: Ramsay, A.T.S. (Ed.), Oceanic Micropaleontology, vol. 1. Academic Press, London, pp. 1-100.

Bé, A.W.H., Huston, W.H., 1977. Ecology of planktonic foraminifera and biogeographic patterns of life and fossil assemblages in the Indian Ocean. Micropaleontology 23, 369-414.

Bassinot, F.C., Guichard, F., Beaufort, L., Shipboard Scientific Party, 1998. IMAGES IV Cruise Report, unpublished report, LSCE, Laboratoire mixte CNRS-CEA, 91198 Gif/Yvette cedex, France.

Bassinot, F.C., Waelbroeck, C., Shipboard Scientific Party, 2002. IMAGES VII Cruise Report, Les Publications de l'Institut Français pour la Recherche et la Technologie Polaires. Les rapports de campagnes à la mer, 01 .

Bemis, B.E., Spero, H.J., Bijma, J., Lea, D.W., 1998. Re-evaluation of the oxygen isotopic composition of planktonic foraminifera: experimental results and revised paleotemperature equations. Paleoceanography 13, 150-160.

Bemis, B.E., Spero, H.J., Lea, D.W., Bijma, J., 2000. Temperature influence on the carbon isotopic composition of Orbulina universa and Globigerina bulloides (planktonic foraminifera). Mar. Micropaleontol. 38, 213-228.

Berger, W.H., Killingley, J.S., 1977. Glacial-Holocene transition in deep-sea carbonates: selective dissolution and the stable isotope signal. Science 197, 563-566.

Bostock, H.C., Opdyke, B.N., Gagan, M.K., Fifield, L.K., 2004. Carbon isotope evidence for changes in Antarctic Intermediate Water circulation and ocean ventilation in the southwest Pacific during the last deglaciation. Paleoceanography 19, A4013. doi:10.1029/2004PA001047.

Bouvier-Soumagnac, Y., Duplessy, J.C., 1985. Carbon and oxygen isotopic composition of planktonic foraminifera from laboratory culture, plankton tows and recent sediment: implications for the reconstruction of paleoclimatic conditions and the global carbon cycle. J. Foraminiferal Res. 25, 24-37.

Chen, M.T., Wang, C.H., Huang, C.Y., Wang, L., Sarnthein, M., 1999. A late Quaternary planktonic foraminifer faunal record of rapid climatic changes from the South China Sea. Mar. Geol. 156, 85-108.

Chen, M.T., Huang, C.C., Pflaumann, U., Waelbroeck, C., Kucera, M., 2005. Estimating glacial western Pacific sea-surface temperature: methodological overview and data compilation of surface sediment planktic foraminifer faunas. Quat. Sci. Rev. 24, 1049-1062.

Cheng, X., Wang, P., 1998. Variation in late Quaternary upper ocean structure of Okinawa Trough: a nannofossil approach. Sci. China, Ser. D 41, 290-296.

Clement, A.C., Seager, R., Cane, M.A., 2000. Suppression of El Niño during the mid-Holocene by changes in the earth's orbit. Paleoceanography 15, 731-737.

Coplen, T.B., Kendall, C., Hopple, J., 1983. Comparison of stable isotope reference samples. Nature 302, 236-238. 
Fairbanks, R.G., Sverdlove, M., Free, R., Wiebe, P.H., Bé, A.W.H., 1982. Vertical distribution and isotopic fractionation of living planktonic foraminifera from the Panama Basin. Nature 298, 841-844

Field, D.B., 2004. Variability in vertical distributions of planktonic foraminifera in the California Current: relationships to vertical ocean structure. Paleoceanography 19, A2014. doi:10.1029/ 2003PA000970.

Hastings, D., Kienast, M., Steinke, S., Whitko, A.A., 2001. A comparison of three independent paleotemperature estimates from a high resolution record of deglacial SST records in the tropical South China Sea. Fall Meet. Suppl., Abstract PP12B-10. Eos Trans. AGU, vol. 82(47).

Hemleben, C., Spindler, M., Anderson, O.R., 1989. Modern Planktonic Foraminifera. Springer-Verlag, New York.

Hilbrecht, H., 1997. Morphologic gradation and ecology in Neogloboquadrina pachyderma and $N$. dutertrei (planktic foraminifera) from core top sediments. Mar. Micropaleontol. 31, 31-43.

Hong, Y.T., Hong, B., Lin, Q.H., Shibata, Y., Hirota, M., Zhu, Y.X., Leng, X.T., Wang, Y., Yi, L., 2005. Inverse phase oscillation between the East Asian and Indian Ocean summer monsoons during the last 12000 years and paleo-El Niño. Earth Planet. Sci. Lett. 231, 337-346.

Huang, C.C., Wu, S.M., Chen, M.T., Lee, M.Y., Wei, K.Y., Huang, C. Y., 2002. Planktic foraminifer faunal sea surface temperature records of the past two glacial terminations in the South China Sea near Wan-An Shallow (IMAGES core MD972151). West. Pac. Earth Sci. 2, 1-14.

Hughen, K.A., Baillie, M.G.L., Bard, E., Bayliss, A., Beck, J.W., Bertrand, C.J.H., Blackwell, P.G., Buck, C.E., Burr, G.S., Cutler, K.B., Damon, P.E., Edwards, R.L., Fairbanks, R.G., Friedrich, M., Guilderson, T.P., Kromer, B., McCormac, F.G., Manning, S.W., Bronk Ramsey, C., Reimer, P.J., Reimer, R.W., Remmele, S., Southon, J.R., Stuiver, M., Talamo, S., Taylor, F.W., van der Plicht, J., Weyhenmeyer, C.E., 2004. Marine04 marine radiocarbon age calibration, 26-0 ka BP. Radiocarbon 46, 1059-1086.

Hut, G., 1987. Consultants Group Meeting on Stable Isotope Reference Samples for Geochemical and Hydrological Investigations. Rep. to Dir. Gen., Int. At. Energy Agency, Vienna.

Ijiri, A., Wang, L., Oba, T., Kawahata, H., Huang, C.Y., Huang, C.Y., 2005. Paleoenvironmental changes in the northern area of the East China Sea during the past 42,000 years. Palaeogeogr. Palaeoclimatol. Palaeoecol. 219, 239-261.

Jian, Z., Li, B., Pflaumann, U., Wang, P., 1996. Late Holocene cooling event in the western Pacific. Sci. China, Ser. D 39, 543-550.

Jian, Z., Wang, P., Saito, Y., Wang, J., Pflaumann, U., Oba, T., Cheng, X., 2000. Holocene variability of the Kuroshio Current in the Okinawa Trough, northwestern Pacific Ocean. Earth Planet. Sci. Lett. 184, 305-319.

Kim, Y.Y., Qu, T., Jensen, T., Miyama, T., Mitsudera, H., Kang, H.W., Ishida, A., 2004. Seasonal and interannual variations of the North Equatorial Current bifurcation in a high-resolution OGCM. J. Geophys. Res. 109, C03040. doi:10.1029/2003JC002013.

Kipp, N.G., 1976. New transfer function for estimating past seasurface conditions from seabed distribution of planktonic foraminiferal assemblages in the North Atlantic. In: Cline, R.M., Hays, J. D. (Eds.), Investigation of Late Quaternary Paleoceanography and Paleoclimatology. Memoir of Geological Society of America, vol. 145, pp. 3-41.

Koutavas, A., Lynch-Stieglitz, J., Marchitto Jr., T.M., Sachs, J.P., 2002. El Niño-like pattern in ice age tropical Pacific sea surface temperature. Science 297, 226-230.
Kroopnick, P.M., 1985. The distribution of ${ }^{13} \mathrm{C}$ of $\Sigma \mathrm{CO}_{2}$ in the world oceans. Deep-Sea Res. 32, 57-84.

Kucera, M., Weinelt, M., Kiefer, T., Pflaumann, U., Hayes, A., Weinelt, M., Chen, M.T., Mix, A.C., Barrows, T.T., Cortijo, E., Duprat, J., Juggins, S., Waelbroeck, C., 2005. Reconstruction of sea-surface temperatures from assemblages of planktonic foraminifera: multi-technique approach based on geographically constrained calibration data sets and its application to glacial Atlantic and Pacific Oceans. Quat. Sci. Rev. 24, 951-998.

Kuroyanagi, A., Kawahata, H., 2004. Vertical distribution of living planktonic foraminifera in the seas around Japan. Mar. Micropaleontol. 53, 173-196.

Lee, S.Y., Huh, C.A., Su, C.C., You, C.F., 2004. Sedimentation in the Southern Okinawa Trough: enhanced particle scavenging and teleconnection between the Equatorial Pacific and western Pacific margins. Deep-Sea Res.: Part 1. Oceanogr. Res. Pap. 51, 1769-1780.

Levitus, S., Boyer, T.P., 1994. World Ocean Atlas 1994: Temperature. NOAA Atlas NESDIS, vol. 4. U.S. Department of Commerce, Washington, DC.

Li, B., Jian, Z., Wang, P., 1997. Pulleniatina obliquiloculata as a paleoceanographic indicator in the southern Okinawa Trough during the last 20,000 years. Mar. Micropaleontol. 32, 59-69.

Li, T.G., Liu, Z.X., Hall, M.A., Berne, S., Saito, Y., Cang, S.X., Cheng, Z.B., 2001. Heinrich event imprints in the Okinawa Trough: evidence from oxygen isotope and planktonic foraminifera. Palaeogeogr. Palaeoclimatol. Palaeoecol. 176, 133-146.

Liang, W.D., Tang, T.Y., Yang, Y.J., Ko, M.T., 2003. Upper-ocean currents around Taiwan. Deep-Sea Res.: Part 2. Top. Stud. Oceanogr. 50, 1085-1105.

Lin, Y.S., 2005. Holocene paleoceanography in the upper reach of the Kuroshio. MS thesis, Natl. Taiwan Univ. Taipei, Taiwan.

Lin, H.L., Wang, L.W., Wang, C.H., Gong, G.C., 1999. Vertical distribution of $\delta^{13} \mathrm{C}$ of dissolved inorganic carbon in the northeastern South China Sea. Deep-Sea Res.: Part 1. Oceanogr. Res. Pap. 46, 757-775.

Lin, H.L., Wang, W.C., Hung, G.W., 2004. Seasonal variation of planktonic foraminiferal isotopic composition from sediment traps in the South China Sea. Mar. Micropaleontol. 53, 447-460.

Liu, C.H., 2004. A Holocene planktic foraminifer record from an IMAGES high resolution core MD972146 of the South China Sea. MS thesis, Natl. Taiwan Ocean Univ. Keelung, Taiwan (in Chinese, with English Abstr.).

Loubere, P., 2001. Nutrient and oceanographic changes in the Eastern Equatorial Pacific from the last full glacial to the present. Glob. Planet. Change 29, 77-98.

Löwemark, L., Hong, W.L., Yui, T.F., Hung, G.W., 2005. A test of different factors influencing the isotopic signal of planktonic foraminifera in surface sediments from the northern South China Sea. Mar. Micropaleontol. 55, 49-62.

Moy, C.M., Seltzer, G.O., Rodbell, D.T., Anderson, D.M., 2002. Variability of El Niño/Southern Oscillation activity at millennial timescales during the Holocene epoch. Nature 420, 162-165.

Mulitza, S., Boltovskoy, D., Donner, B., Meggers, H., Paul, A., Wefer, G., 2003. Temperature: $\delta^{18} \mathrm{O}$ relationships of planktonic foraminifera collected from surface waters. Palaeogeogr. Palaeoclimatol. Palaeoecol. 202, 143-152.

Niebler, H.S., Hubberten, H.W., Gersonde, R., 1999. Oxygen isotope values of planktonic foraminifera: a tool for the reconstruction of surface water stratification. In: Fischer, G., Wefer, G. (Eds.), Use of Proxies in Paleoceanography: Examples from the South Atlantic. Springer-Verlag, Berlin, pp. 165-189. 
Pan, Z., Liang, S., Ding, P., 1988. Geological significance of microbiotas in the Okinawa Trough. In: Hao, Y., Ding, P. (Eds.), Quaternary Microbiotas in the Okinawa Trough and Their Geological Significance. Geological Publishing House, Beijing, pp. 119-145 (in Chinese, with English abstract).

Parker, F.L., 1962. Planktonic foraminiferal species in Pacific sediments. Micropaleontology 8, 219-254.

Patrick, A., Thunell, R.C., 1997. Tropical Pacific sea surface temperatures and upper water column thermal structure during the last glacial maximum. Paleoceanography 12, 649-657.

Peng, Y., Xiao, J., Nakamura, T., Liu, B., Inouchi, Y., 2005. Holocene East Asian monsoonal precipitation pattern revealed by grain-size distribution of core sediments of Daihai Lake in Inner Mongolia of north-central China. Earth Planet. Sci. Lett. 233, 467-479.

Pflaumann, U., Jian, Z., 1999. Modern distribution patterns of planktonic foraminifera in the South China Sea and western Pacific: a new transfer technique to estimate regional sea-surface temperatures. Mar. Geol. 156, 41-83.

Qiu, B., Lukas, R., 1996. Seasonal and interannual variability of the North Equatorial Current, the Mindanao Current, and the Kuroshio along the Pacific western boundary. J. Geophys. Res. 101, $12315-12330$.

Qu, T., Lukas, R., 2003. The bifurcation of the North Equatorial Current in the Pacific. J. Phys. Oceanogr. 33, 5-18.

Qu, T., Kim, Y.Y., Yaremchuk, M., Tozuka, T., Ishida, A., Yamagata, T., 2004. Can Luzon Strait transport play a role in conveying the impact of ENSO to the South China Sea? J. Clim. 17, 3644-3657.

Ravelo, A.C., Fairbanks, R.G., 1992. Oxygen isotopic composition of multiple species of planktonic foraminifera: recorders of the modern photic zone temperature gradient. Paleoceanography 7 , 815-831.

Rein, B., Lückge, A., Reinhardt, L., Sirocko, F., Wolf, A., Dullo, W.C., 2005. El Niño variability off Peru during the last 20,000 years. Paleoceanography 20, A4003. doi:10.1029/2004PA001099.

Rohling, E.J., Sprovieri, M., Cane, T., Casford, J.S.L., Cooke, S., Bouloubassi, I., Emeis, K.C., Schiebel, R., Rogerson, M., Hayes, A., Jorissen, F.J., Kroon, D., 2004. Reconstructing past planktic foraminiferal habitats using stable isotope data: a case history for Mediterranean sapropel S5. Mar. Micropaleontol. 50, 89-123.

Russell, A.D., Spero, H.J., 2000. Field examination of the oceanic carbonate ion effect on stable isotopes in planktonic foraminifera. Paleoceanography 15, 43-52.

Sandweiss, D.H., Richardson III, J.B., Reitz, E.J., Rollins, H.B., Maasch, K.A., 1996. Geoarchaeological evidence from Peru for a 5000 years B.P. onset of El Niño. Science 273, 1531-1533.

Schweitzer, P.N., Lohmann, G.P., 1991. Ontogeny and habitat of modern menardiform planktonic foraminifera. J. Foraminiferal Res. 21, 332-346.

Shen, C.C., Hastings, D.W., Lee, T., Chiu, C.H., Lee, M.Y., Wei, K.Y., Edwards, R.L., 2001. High precision glacial-interglacial benthic foraminiferal $\mathrm{Sr} / \mathrm{Ca}$ records from the eastern equatorial Atlantic Ocean and Caribbean Sea. Earth Planet. Sci. Lett. 190, 197-209.

Shen, C.C., Chiu, H.I., Chu, M.F., Chen, M.T., Wei, K.Y., Steinke, S., 2004. High precision measurement of $\mathrm{Mg} / \mathrm{Ca}$ and $\mathrm{Sr} / \mathrm{Ca}$ ratios in carbonates by cool plasma quadrupole inductively coupled plasma mass spectrometry. Fall Meet. Suppl., Abstract PP23B-1440. Eos Trans. AGU, 84 (46).

Shieh, Y.T., 1993. The paleoceanography off eastern Taiwan during late Quaternary. PhD thesis, Natl. Taiwan Univ. Taipei, Taiwan (in Chinese, with English Abstr.).

Shieh, Y.T., Chen, M.P., 1990. Planktonic foraminiferal assemblages within the surface $200 \mathrm{~m}$ water, across the Kuroshio Current, June,
1990. Acta Oceanogr. Taiwan. 25, 87-98 (in Chinese, with English Abstr.).

Spero, H.J., 1992. Do planktic foraminifera accurately record shifts in the carbon isotopic composition of seawater $\Sigma \mathrm{CO}_{2}$ ? Mar. Micropaleontol. 19, 275-285.

Spero, H.J., Williams, D.F., 1988. Extracting environmental information from planktonic foraminiferal $\delta^{13} \mathrm{C}$ data. Nature 335 , 717-719.

Spero, H.J., Bijma, J., Lea, D.W., Bemis, B.E., 1997. Effect of seawater carbonate concentration on foraminiferal carbon and oxygen isotopes. Nature 390, 497-500.

Spero, H.J., Mielke, K.M., Kalve, E.M., Lea, D.W., Pak, D.K., 2003. Multispecies approach to reconstructing eastern equatorial Pacific thermocline hydrography during the past 360 kyr. Paleoceanography 18, 1022. doi:10.1029/2002PA000814.

Steinke, S., Chiu, H.I., Yu, P.S., Shen, C.C., Löwemark, L., Mii, H.S., Chen, M.T., 2005. Mg/Ca ratios of two Globigerinoides ruber (white) morphotypes: implications for reconstructing past tropical/ subtropical surface water conditions. Geochem. Geophys. Geosyst. 6, Q11005. doi:10.1029/2005GC000926.

Stuiver, M., Reimer, P.J., Reimer, R.W., 2005. CALIB 5.0 (http:// radiocarbon.pa.qub.ac.uk/calib/).

Sun, Y., Oppo, D.W., Xiang, R., Liu, W., Gao, S., 2005. Last deglaciation in the Okinawa Trough: subtropical northwest Pacific link to northern hemisphere and tropical climate. Paleoceanography 20, A4005. doi:10.1029/2004PA001061.

Thompson, P.R., 1981. Planktonic foraminifera in the western North Pacific during the past 150,000 years: comparison of modern and fossil assemblages. Palaeogeogr. Palaeoclimatol. Palaeoecol. 35, 241-279.

Thunell, R., Miao, Q., Calvert, S.E., Pedersen, T.F., 1992. GlacialHolocene biogenic sedimentation patterns in the South China Sea: productivity variations and surface water $\mathrm{pCO}_{2}$. Paleoceanography 7, 143-162.

Tian, J., Wang, P., Chen, R., Cheng, X., 2005. Quaternary upper ocean thermal gradient variations in the South China Sea: implications for east Asian monsoon climate. Paleoceanography 20, A4007. doi:10.1029/2004PA001115.

Ujiié, H., Ujiié, Y., 1999. Late Quaternary course changes of the Kuroshio Current in the Ryukyu Arc region, northwestern Pacific Ocean. Mar. Micropaleontol. 37, 23-40.

Ujiié, Y., Ujiié, H., 2000. Distribution and oceanographic relationships of modern planktonic foraminifera in the Ryukyu Arc region, Northwest Pacific Ocean. J. Foraminiferal Res. 30, 336-360.

Ujiié, Y., Ujiié, H., Taira, A., Nakamura, T., Oguri, K., 2003a. Spatial and temporal variability of surface water in the Kuroshio source region, Pacific Ocean, over the past 21,000 years: evidence from planktonic foraminifera. Mar. Micropaleontol. 49, 335-364.

Ujiié, Y., Watanabe, N., Ikehara, M., Ashi, J., 2003b. Drastic change of the subtropical circulation in the super El Niño-like condition during late Holocene: evidence from the fluctuation of the Kuroshio Current. Fall Meet. Suppl., Abstract PP22A-1202. Eos Trans, AGU, vol. 84 (46).

Wang, L., 2000. Isotopic signals in two morphotypes of Globigerinoides ruber (white) from the South China Sea: implications for monsoon climate change during the last glacial cycle. Palaeogr. Palaeoclimatol. Palaeoecol. 161, 381-394.

Wang, L., Sarnthein, M., Erlenkeuser, H., Grimalt, J., Grootes, P., Heilig, S., Ivanova, E., Kienast, M., Pelejero, C., Pflaumann, U., 1999. East Asian monsoon climate during the Late Pleistocene: high-resolution sediment records from the South China Sea. Mar. Geol. 156, 245-284. 
Watkins, J.M., Mix, A.C., Wilson, J., 1996. Living planktonic foraminifera: tracers of circulation and productivity regimes in the central equatorial Pacific. Deep-Sea Res.: Part 2. Top. Stud. Oceanogr. 43, 1257-1282.

Watkins, J.M., Mix, A.C., Wilson, J., 1998. Living planktonic foraminifera in the central Pacific Ocean: articulating the equatorial 'cold tongue' during La Niña, 1992. Mar. Micropaleontol. 33, 157-174.

Wei, K.Y., Mii, H., Huang, C.-Y., 2005. Age model and oxygen isotope stratigraphy of Site ODP1202 in the southern Okinawa Trough, northwestern Pacific. Terr. Atmos. Ocean. Sci. (TAO) 16, $1-17$.

Wu, W., Liu, T., 2004. Possible role of the "Holocene Event 3" on the collapse of Neolithic Cultures around the Central Plain of China. Quat. Int. 117, 153-166.
Xu, X., Yamasaki, M., Oda, M., Honda, M.C., 2005. Comparison of seasonal flux variations of planktonic foraminifera in sediment traps on both sides of the Ryukyu Islands, Japan. Mar. Micropaleontol. 58, 45-55.

Yamasaki, M., Oda, M., 2003. Sedimentation of planktonic foraminifera in the East China Sea: evidence from a sediment trap experiment. Mar. Micropaleontol. 49, 3-20.

Yu, P.S., Chiu, T.C., Chen, M.T., Wei, K.Y., Chen, Y.G., 2000. Planktic foraminifer faunal assemblage and sea-surface temperature variations in a 'warm-pool' South China Sea record of the past 400,000 years: IMAGES core MD972142. J. Geol. Soc. China 43, 467-496. 